\title{
KONFERENCJA WYŻSZYCH PRZEŁOŻONYCH ŻEŃSKICH ZGROMADZEŃ ZAKONNYCH I KONSULTA W PRL. ZARYS PROBLEMATYKI
}

Konferencje wyższych przełożonych zgromadzeń zakonnych to związki o charakterze kolegialnym, posiadające osobowość prawną, erygowane przez Stolicę Apostolską oraz działające w oparciu o zatwierdzone przez nią statuty. Konferencje powołuje się celem inicjowania oraz koordynacji współpracy między zakonami, kooperacji zgromadzeń zakonnych z Konferencjami Episkopatu, jak również poszczególnymi biskupami. Początki instytucji konferencji wyższych przełożonych w świecie, sięgają pontyfikatu Piusa XII oraz ówczesnych debat na temat odnowy życia konsekrowanego, prowadzonych przez zakonników pod papieskimi auspicjami. W Polsce, proces formowania konferencji wyższych przełożonych zgromadzeń zakonnych przypadł na okres, w którym działały już zorganizowane struktury współpracy międzyzakonnej żeńskiej i męskiej, wykształcone dla wspólnej obrony zakonników przed negatywnymi skutkami polityki wyznaniowej władz komunistycznych, wdrażających sowiecki model rozdziału Kościoła od państwa oraz realizujących program likwidacji instytucji podległych Kościołowi rzymsko-katolickiemu.

\section{Geneza instytucji konferencji wyższych przełożonych}

Tworzenie konferencji wyższych przełożonych zgromadzeń zakonnych w świecie to rezultat prac Kongregacji do Spraw Zakonów ${ }^{1}$ oraz pochodna obrad

* S. Joanna Wiśniewska - mgr teologii, doktorantka w Instytucie Nauk Historycznych UKSW w Warszawie, e-mail: s.joanna.am@gmail.com

${ }^{1}$ Papież Paweł VI konstytucją Regimini Ecclesiae Universae z 1967 r. zmienił jej nazwę na Kongregację Zakonów i Instytutów Świeckich; obecnie: Kongregacja do Spraw Instytutów Życia Konsekrowanego i Stowarzyszeń Życia Apostolskiego. Przy Kongregacji działa Międzynarodowa Unia Przełożonych Generalnych. Do kompetencji Kongregacji należy erygowanie instytutów zakonnych i świeckich, stowarzyszeń życia apostolskiego, ich znoszenie, dokonywanie unii i federacji, troska o ich rozwój, a także erygowanie konferencji wyższych przełożonych oraz zatwierdzanie ich statutów. Zob. Konstytucja Apostolska Kurii Rzymskiej Pastor Bonus z dn. 28 czerwca 1988, art. 
międzynarodowych kongresów zakonnych, przypadających na początek lat pięćdziesiątych XX wieku².

Systematyczne wysiłki rzymskiej Kongregacji, podyktowane potrzebą odnowy życia konsekrowanego, zaowocowały dekretem Salutaris atque fecundus z dn. 26 marca 1956 r. ${ }^{3}$ Dokument zakładał fakt zawiązywania się rad przełożonych wyższych oraz porządkował zasady zwoływania zjazdów. Funkcjonowanie powstałych związków ponad-zgromadzeniowych, według wytycznych dekretu, miało być regulowane statutami, zatwierdzanymi przez Stolicę Apostolską ${ }^{4}$. Rady, inspirowane konferencjami biskupów, powołane były do pracy kolegialnej. Zobowiązane zostały do poszanowania autonomii każdego instytutu ${ }^{5}$ oraz specyficznej roli zakonów w Kościele i społeczeństwie. Do istotnych warunków współdziałania wyższych przełożonych, zaliczano respektowanie tradycyjnej duchowości zrzeszonych zgromadzeń oraz ich ukierunkowanej aktywności, wynikającej $\mathrm{z}$ fundamentalnych koncepcji założycielskich ${ }^{6}$.

105-111, w: AAS 80 (1988), 886-888; M. Daniluk, Konferencje Wyższych Przełożonych, w: Encyklopedia katolicka, t. 9, Lublin 2002, k. 612-613.

${ }^{2}$ Od 1946 r. we Francji pojawiły się liczne publikacje o konieczności odnowy życia zakonnego, przestrzegające przed spadkiem liczby powołań i niedostosowaniem zakonów do aktualnych warunków. W 1950 r. odbył się pierwszy światowy kongres, nazwany zgodnie z ówcześnie obowiązującą nomenklaturą Kongresem Stanów Doskonałości (stan doskonałości utożsamiany był w Kościele z życiem zakonnym - Kodeks Prawa Kanonicznego z 1917 r., kan. 488 i 593. Nazwa zwracać miała uwagę na cel ogólny każdego zakonu, tzn. osiągnięcie doskonałości członków. Budziła jednak tak wiele kontrowersji, że w nowym KPK zastąpiona została terminem: życie konsekrowane. Więcej: J. Bar, Prawo zakonne po Soborze Watykańskim II, Warszawa 1977, s. 9-11; M. Daniluk, Stan doskonatości, w: Encyklopedia instytutów życia konsekrowanego i stowarzyszeń życia apostolskiego, red. M. Daniluk, Lublin 2000, s. 348), pod hasłem accomodata renovatio, podczas którego zastanawiano się nad trzema zasadniczymi aspektami odnowy: dyscypliną, formacją i apostolatem. Akta kongresu wydano w 1950 r. w Rzymie w czterech tomach zatytułowanych: Acta et Documenta Congressus Generalis de Statibus Perfectionis. Po 1950 r. z inicjatywy Kongregacji Zakonów miały miejsce inne kongresy oraz zjazdy wyższych przełożonych zarówno instytutów męskich, jak i żeńskich. W 1951 r. np. zwołany został Kongres Zakonów Nauczających postulujący pogłębienie wykształcenia zawodowego i teologicznego zakonnic oraz tworzenia junioratów jako przedłużenia formacji nowicjackiej, a w 1952 r. I Kongres Przełożonych Wyższych Zgromadzeń Zakonnych Żeńskich. Ze strony samego papieża Piusa XII, kierowane były do zakonników zalecenia wyjścia zgromadzeń ze stanu odosobnienia i ożywienia apostolstwa zgodnie z wymogami czasu. Por. J. Bar, J. Kałowski, Prawo o instytutach życia konsekrowanego, Warszawa 1985, s. 85-87.

${ }^{3}$ Rzymska Kongregacja do Spraw Zakonów, zajmująca się organizacją kongresów wyższych przełożonych, dostrzegając znaczne nasilenie zjazdów międzyzakonnych po 1953 r. oraz zapobiegając ewentualnym nadużyciom, uporządkowała nowe zjawisko specjalnym dekretem, regulującym współpracę międzyzakonną na każdym szczeblu (diecezjalnym, regionalnym, krajowym i in.). Zob. AAS 48 (1956) 295-296.

${ }^{4}$ Por. J. Bar, Konferencje Wyższych Przetożonych zakonów w Polsce, „Prawo Kanoniczne”, 23 (1980) nr 3-4, s. 100-101.

${ }^{5}$ Autonomia instytutu to uznane w KPK (kan. 586) fundamentalne prawo instytutów życia konsekrowanego i stowarzyszeń życia apostolskiego do własnej struktury wewnętrznej i niezależności od innych osób prawnych oraz biskupów ordynariuszy. Jest to niezawisłość niezbędna do zachowania specyficznego charakteru instytutów, które mogą jednak w wielu sprawach podlegać władzy zewnętrznej najwyższej (kan. 590, 593, 605) oraz diecezjalnej (kan. 678).

${ }^{6}$ Por. Daniluk, Konferencje Wyższych Przełożonych, k. 575-576. 
Sporadyczne początkowo zjazdy przełożonych wyższych, ewoluowały z biegiem czasu wraz ze wrastającym doświadczeniem zakonników i pojawiającymi się wyzwaniami. Okazjonalne zebrania przekształciły się stopniowo w stałe rady o różnych nazwach (unie, konferencje, konfederacje) oraz zróżnicowanym stopniu centralizacji. Działały poprzez zgromadzenia ogólne, stałe komitety kierownicze (jak rada dyrekcji, komitet wykonawczy, konsultę, zespół zarządzający) oraz przez komisje problemowe ${ }^{7}$. W poszczególnych państwach zakonnicy i zakonnice zakładali, najczęściej całkowicie niezależne od siebie, konferencje - żeńskie i męskie, z okresowymi spotkaniami wspólnymi ${ }^{8}$. W niektórych krajach istniała tylko jedna taka konferencja (10 państw), a czasem kilka w jednym państwie, ze względu na różnorodność kultur i języków9.

Zdołano oprócz tego utworzyć powiązania międzynarodowe, z których wymienić należałoby przede wszystkim: 1) Unię Przełożonych Generalnych Instytutów Męskich (USG), 2) Międzynarodową Unię Przełożonych Generalnych Instytutów Żeńskich (UISG), 3) Unię Europejskich Konferencji Wyższych Przełożonych - męskich i żeńskich (UCESM) ${ }^{10}$.

Stojące u podstaw zawiązywania się konferencji stare adagium - Ecclesia semper reformanda - wybrzmiało postulatami odnowy i aggiornamento życia za-

${ }^{7}$ Bar, Konferencje Wyższych Przełożonych, s. 100-101.

${ }^{8}$ Tenże, Łączność między przełożonymi różnych zakonów, w: Prawo zakonne po Soborze, s. $129-131$.

${ }^{9}$ Cz. Parzyszek, Życie konsekrowane w posoborowym nauczaniu Kościoła, Ząbki 2007, s. 322 .

10 1) USG wyrosła ze spotkań przełożonych generalnych rezydujących w Rzymie. Ukonstytuowana została w 1955 r. przez Kongregację Zakonów w Komitet Centralny Przełożonych Generalnych Instytutów Doskonałości, a w 1957 r. w Unię Rzymską Przełożonych Generalnych, której nazwę w 1967 r. zmieniono na obecną. Statut Unii zatwierdzony został w 1955 r., a później zmodyfikowany. USG to międzynarodowe porozumienie zrzeszające przełożonych generalnych instytutów i stowarzyszeń życia apostolskiego na prawie papieskim. Priorytetami USG stały się: kooperacja instytutów i stowarzyszeń oraz troska o podtrzymywanie należytej relacji i współpracy zakonów męskich ze Stolicą Apostolską oraz hierarchią Kościoła. Spektakularnym osiągnięciem Unii był udział członków USG w pracach nad dokumentami: Ecclesiae Sancte, Renovationis Causam oraz Mutuae relationes. Przy Kongregacji Zakonów i Instytutów Świeckich powołano radę Unii jako stały organ, z którym z kolei konsultowano adhortację Evangelica testificatio.

2) UISG z siedzibą w Rzymie, erygowana została przez Kongregację Zakonów w 1965 r. Unia składała się z dwóch stopni - rady generalnej złożonej z 20 przełożonych generalnych oraz zgromadzenia delegatek, zwoływanego co 3 lata. Jej statuty zmienione w 1986 r., zatwierdziła w 1988 r. Kongregacja Zakonników i Instytutów Świeckich.

3) UCESM, wykształciła się ze spotkań sekretarzy generalnych konferencji wyższych przełożonych Europy, odbywających się co roku od 1958. Ukonstytuowana została w 1981 r. Pierwsze zgromadzenie UCESM odbyło się w 1983 r. Za nadrzędny cel UCESM uznało propagowanie współpracy między poszczególnymi konferencjami i innymi organizacjami europejskimi. Obecnie UCESM skupia ok. 40 konferencji z 25 krajów europejskich; reprezentuje ok. 400 tys. zakonnic i zakonników. UCESM od 1996 r. posiada swój stały sekretariat w Brukseli. Zebrania plenarne UCESM odbywają się co dwa lata w różnych krajach europejskich. W 2010 r. spotkanie Unii miało miejsce w Polsce. Por. Daniluk, Konferencje Wyższych Przełożonych, k. 575-576; Parzyszek, Życie konsekrowane w posoborowym nauczaniu, s. 322. 
konnego, zwłaszcza podczas Vaticanum $\mathrm{II}^{11}$. Zapoczątkowany wówczas swoisty cykl dokumentów, przybliżający temat współpracy między zakonami, doczekał się swojej kontynuacji w posoborowym nauczaniu Kościoła ${ }^{12}$. Wzmocnił tym samym znaczenie dotychczasowych regionalnych i międzynarodowych związków oraz zainicjował kolejne.

Szczególne miejsce wśród dokumentów poruszających sprawę konferencji wyższych przełożonych, zajął Kodeks Prawa Kanonicznego (1983), zbierający dotychczasowy dorobek refleksji oraz rozwiązań praktycznych. W myśl KPK, wyższym przełożonym zakonnym przysługuje prawo łączenia się w konferencje (rady) i wspólnej pracy nad pełniejszym osiągnięciem celu poszczególnych insty-

${ }^{11}$ Dekret Perfecte Caritatis (1965), popierał tworzenie konferencji wyższych przełożonych, ponieważ pomagały w pełniejszej realizacji celów instytutów, współpracy z hierarchią Kościoła oraz lepszym gospodarowaniu energią zakonów. Zob. Dekret o przystosowanej do wspótczesności odnowie życia zakonnego «Perfecte caritatis», w: Sobór Watykański II. Konstytucje, dekrety, deklaracje. Tekst polski. Nowe tlumaczenie, Poznań 2002, s. 264-275. Współpracę miedzy instytutami zakonnymi a klerem diecezjalnym popierał z kolei dekret Christus Dominus (1965), wzywając Konferencje Biskupów i konferencje wyższych przełożonych do wytyczania wspólnych planów. Zob. Dekret o pasterskich zadaniach biskupów w Kościele "Christus Dominus», w: Sobór Watykański II, s. 248-251. Dekret Ad gentes (1965), wzywał zakonników, by wykorzystywali możliwości, jakie dają konferencje, do skuteczniejszego organizowania pracy na terenach misyjnych. Zob. Dekret o misyjnej działalności Kościoła «Ad gentes», w: Sobór Watykański II, s. 469-470.

${ }^{12}$ Dokument Ecclesiae Sancte (1966), odgrywał znaczącą rolę we wprowadzaniu w życie nauki soborowej. Był praktycznym przewodnikiem dla instytutów zakonnych w ogólnie zarysowanym przez Perfecte caritatis procesie przystosowanej do współczesności odnowy życia zakonnego. ES doceniał wagę konferencji wyższych przełożonych oraz tworzonych unii. Przy okazji, podkreślał konieczność współpracy zakonników z konferencjami biskupów. Dopominał się przy tym o komisje mieszane, złożone z biskupów oraz wyższych przełożonych zakonów żeńskich i męskich. Zob. Motu proprio: Normy i przepisy wykonawcze do Dekretów Soboru Watykańskiego II «Ecclesiae Sancte», w: Paweł VI, Charyzmat życia zakonnego. Przemówienia i dokumenty, Poznań-Warszawa 1974, s. 216-225. Problem zauważalnego napięcia między angażowaniem zakonników w coraz szerszą przestrzeń duszpasterską Kościoła lokalnego a zachowaniem tożsamości własnej osób konsekrowanych oraz związane z tym relacje między biskupami a konferencjami wyższych przełożonych prezentował dokument Mutuae relationes (1978). Dokument okazał się decydujący dla zawiązania się w poszczególnych krajach komisji mieszanych, złożonych z przedstawicieli biskupów i przełożonych wyższych zakonów męskich i żeńskich (zob. Kongregacja Zakonów i Instytutów Świeckich oraz Kongregacja Biskupów, Wytyczne dla wzajemnych stosunków między biskupami i zakonnikami w Kościele «Mutuae relationes», w: Jan Paweł II, O życiu zakonnym. Przemówienia, Listy apostolskie, Instrukcje, Poznań-Warszawa, 1984, s. 333-373). Sprawę komisji mieszanych poruszał również dokument Postquam Apostoli (1980), zob. Kongregacja Duchowieństwa, Wytyczne do popierania wzajemnej wspótpracy Kościołów partykularnych, a zwłaszcza do właściwego rozmieszczenia kleru «Postquam Apostoli», w: AAS 72 (1980), s. 347-348 i 359-360. Według wytycznych Kościoła, konferencje wyższych przełożonych oraz konferencje biskupów, stać miały na straży specyficznych zadań życia konsekrowanego. Ponadto ich zadaniem było czuwanie nad uczestnictwem zakonników w dziele ewangelizacji i promocji ludzkiej. Z apelem w tej sprawie wystąpiła Kongregacja do Spraw Zakonów i Instytutów Świeckich, za pośrednictwem dokumentu Optiones ewangelicae (1980). Zob. Kongregacja Zakonów i Instytutów Świeckich, Zakonnicy i promocja ludzka «Optiones evangelicae», w: Jan Paweł II, O życiu zakonnym, Poznań 1984, s. 374-400. 
tutów (kan. 708). W Kodeksie pokreślona została sprawa zachowania autonomii zgromadzenia zakonnego, jego charakteru i duchowości. Ponadto dokument przypominał o konieczności nawiązania odpowiedniej współpracy konferencji wyższych przełożonych z Konferencjami Episkopatu, jak również z poszczególnymi biskupami. Konferencje musiały posiadać własne statuty, zatwierdzone przez Stolicę Apostolską. Z jej nadania konferencje nabywały osobowość prawną (kan. 709).

\section{Zawiązywanie się konferencji w Polsce}

Ruch odnowy życia konsekrowanego powoli docierał do Polski. Nie on jednak przesądził o powstaniu w naszej Ojczyźnie współpracy między zakonami. Wymusiła ją przede wszystkim - niesprzyjająca Kościołowi - sytuacja polityczna. Zaznaczyć jednak należy, że i zgromadzeniom zakonnym w Polsce nieobce były inspiracje płynące z Watykanu ${ }^{13}$.

Jedną $\mathrm{z}$ form współpracy międzyzakonnej w Polsce były konferencje wyższych przełożonych zgromadzeń zakonnych żeńskich i męskich. Konferencja Wyższych Przełożonych Zakonów Męskich w Polsce faktycznie powstała pod koniec 1948 r. z inicjatywy kilku prowincjałów (projektodawcą był o. Bonawentura Kadeja, pijar). W tym samym roku, wybrano prezydium zjazdów wyższych przełożonych zakonów męskich. W 1954 r. prezydium zostało przekształcone w Referat Spraw Zakonnych przy przewodniczącym Episkopatu Polski. Prymas Wyszyński w 1957 r. powołał męską konsultę ${ }^{14}$ z siedzibą przy Wydziale Spraw Zakonnych ${ }^{15}$. Konsulta działała w oparciu o statut zatwierdzony w 1958 r., definiujący konferencję jako wzajemne porozumienie wyższych przełożonych, bez władzy zwierzchniej nad zakonami w Polsce ${ }^{16}$. Konferencja została erygowana kanonicznie w 1963 r. przez rzymską Kongregację do Spraw Zakonów, uzyskując zatwierdzenie statutu oraz osobowość prawną ${ }^{17}$.

${ }^{13}$ Przykładowa wypowiedź Prymasa jeszcze przed SW II: „Zachęta i przykład Stolicy św., ciągłe wskazania Piusa XII, Zjazdy Międzynarodowe Rodzin Zakonnych, odbywane w Rzymie i we Francji - są dowodem, jak praca zapoczątkowana w Polsce przez ś.p. Ks. Kardynała - Prymasa Hlonda, a przez nas prowadzona dalej, była na czasie i jak doniosłe przynosi już dziś owoce. (...) Potrzeba coraz czulszej wrażliwości wszystkich Rodzin Zakonnych na głos Stolicy Świętej, która przez Ojca św. Piusa XII stawia Zakonom coraz to nowe wymagania i stara się wyprowadzić je z odosobnienia, by użyć do pracy apostolskiej, do współpracy z Hierarchią, do współdziałania wszystkich Rodzin zakonnych ze sobą, przez Krajowe Porozumienia Zakonne, przez powołane przez Biskupów w tym celu stałe Komisje Wyższych Przełożonych Zakonnych, Konsultorki itp.” Archiwum Instytutu Prymasowskiego (dalej: AIP), St. kard. Wyszyński, List do Sióstr. Komańcza, dn. 12 lipca 1956, w: S. Wyszyński, Przemówienia do zakonnic 1956-1960, t. 1, s. 2-3 (mps, b. sygn.).

${ }^{14}$ Konsulta to organ wykonawczy konferencji wyższych przełożonych zakonnych. W omawianym okresie była organem doradczym Prymasa Polski, działającym w imieniu wyższych przełożonych. Więcej: Daniluk, Konsulta Wyższych Przełożonych, w: Encyklopedia instytutów, s. 205.

${ }^{15}$ Por. Bar, Konferencje Wyższych Przełożonych, s. 103-105.

${ }^{16}$ Por. Archiwum Konferencji Wyższych Przełożonych Męskich Zgromadzeń Zakonnych, Ramowy Statut Konferencji Wyższych Przełożonych Zakonów Męskich w Polsce, z dn. 15 kwietnia 1958 r., N. 2431/58/P.

${ }^{17}$ Por. Bar, Konferencje Wyższych Przełożonych, s. 115. Szerzej zob.: D. Zamiatała, Konferencja Wyższych Przełożonych Zakonów Męskich w Polsce i Konsulta zakonna PRL, w: „Archiwa, Biblioteki i Muzea Kościelne" (dalej: ABMK), 92 (2009) s. 326-327. 
Konferencja wyższych przełożonych żeńskich zgromadzeń zakonnych podobnie jak męskich, bazowała na wypracowanym po wojnie doświadczeniu wspólnego działania instytutów. Powstanie konferencji żeńskiej przypadło na okres gierkowski, jednak istotne elementy instytucji, pojawiły się już dużo wcześniej: zebrania (plenum), konsulta (komisja międzyzakonna) i praca międzyzakonna zorganizowana w sekcjach. Prymas Wyszyński uważał, że prowadzona od lat działalność konsultorek ${ }^{18}$, jak również aprobata Stolicy Apostolskiej dla samej instytucji konsulty, były wystarczająco przekonywującym argumentem, przemawiającym za uznaniem istnienia żeńskiej konsulty w Polsce, jeszcze przed jej oficjalnym ustanowieniem ${ }^{19}$. Organizowane natomiast zjazdy wyższych przełożonych żeńskich zgromadzeń zakonnych, $\mathrm{z}$ czasem zyskały status prawny organu konferencji, określanego mianem zjazdów plenarnych.

Porządkując oraz dostosowując do wytycznych Kościoła i polskich realiów, struktury międzyzakonnej współpracy żeńskiej, Prymas Wyszyński nadał w 1960 r. tzw. normy oraz prawnie ustanowił konsultę żeńską ${ }^{20}$. Konferencja Wyższych Przełożonych Żeńskich Zgromadzeń Zakonnych w Polsce została erygowana przez rzymską Kongregację Zakonów w 1970 r. ${ }^{21}$

Cechami charakterystycznymi żeńskiej współpracy międzyzakonnej, zapoczątkowującej instytucję konferencji wyższych przełożonych żeńskich zgromadzeń zakonnych, były: 1) przeobrażenia form współpracy; 2) ścisły związek wyższych przełożonych z Kościołem hierarchicznym reprezentowanym przez Prymasa Polski, biskupów diecezjalnych oraz Wydział Spraw Zakonnych; 3) wspólne problemy zgromadzeń żeńskich: a) pozbawienie możliwości działania i materialnych podstaw koniecznych do przetrwania instytutów oraz prowadzonych dzieł; b) przekształcenia jakościowe instytutów żeńskich na skutek poważnego zaangażowania $\mathrm{w}$ pracę parafialną 22 .

\section{Uwarunkowania polityczne powstania konferencji żeńskiej}

Zalążki polskiej współpracy zakonów żeńskich, pojawiły się już w międzywojniu, w związku z problemami zakonów, które zajmowały się działalnością oświatowo-wychowawczą (dot. przede wszystkim: urszulanek OSU, niepokalanek, nazaretanek, zmartwychwstanek i felicjanek). Siostry zakonne, mimo wysokich osiągnięć w pracy, spotykały się z negatywnymi ocenami wizytatorów państwowych. Obawiały się odgórnego paraliżowania działalności wychowawczej szkół zakonnych, odbierania uprawnień państwowych, a tym samym powolnego

${ }^{18}$ Por. A. Łączka, Wspomnienia o wspótpracy międzyzakonnej zgromadzeń zakonnych żeńskich w Polsce po II wojnie światowej do 1960 r., Warszawa 1984, t. 1, s. 29 (mps w sekretariacie Konferencji Wyższych Przełożonych Żeńskich Zgromadzeń Zakonnych).

${ }^{19}$ Por. AIP, S. Wyszyński, Do matek konsultorek i referentek diecezjalnych, 8 stycznia 1957 r., Warszawa, w: tenże, Przemówienia, t. 1, Warszawa, s. 34-37.

${ }^{20}$ Por. Archiwum Prymasa Polski, Dekret Prymasa Polski z dn. 4 czerwca 1960 r., w: Konsulta Wyższych Przełożonych Zakonów Żeńskich od 1957-1983, teczka nr 123, b.p. (zawartość teczki uporządkowana chronologicznie).

${ }^{21}$ Bar, Konferencje wyższych przełożonych, s. 111.

${ }^{22}$ Por. Łączka, Wspomnienia o wspótpracy międzyzakonnej, t. 1, s. 27; 43-45. 
likwidowania placówek ${ }^{23}$. Inicjatorkami stworzenia wspólnej obrony żeńskich zgromadzeń nauczających były: s. Cecylia Łubieńska ${ }^{24}$, urszulanka OSU oraz s. Zenona Dobrowolska ${ }^{25}$, niepokalanka. Siostry zorganizowały dwa pedagogiczne zjazdy międzyzakonne ${ }^{26}$. Wybuch II wojny światowej pokrzyżował wspólne plany, które zaraz po wojnie, musiały zostać wznowione. Inicjatywę po swoich poprzedniczkach przejęła s. Emanuela Mrozowskaa ${ }^{27}$, urszulanka OSU.

W okresie powojennym, wrogi stosunek władz państwowych wobec katolicyzmu, wymagający od sióstr zakonnych solidarności i konsolidacji sił na wszystkich polach działania, okazał się decydujący w procesie powstawania konferencji wyższych przełożonych żeńskich zgromadzeń zakonnych w Polsce. Gwarancją bowiem, dalszego bytu zgromadzeń żeńskich, stało się konstruowanie, pod kierunkiem Prymasa Polski, najpierw kard. Augusta Hlonda, następnie Stefana Wyszyńskiego, wspólnych programów przetrwania i funkcjonowania w peerelowskiej rzeczywistości, tworzenie forum wymiany informacji i doświadczeń, jak również uzgadnianie i konsekwentne zachowanie jednolitej postawy wobec państwa. Możliwość prowadzenia takich integracyjnych działań, wpisana była w samą naturę instytucji konferencji ${ }^{28}$.

Dążenie do całkowitego zawłaszczenia przestrzeni publicznej przez państwo, prowadziło do stopniowej eliminacji sióstr zakonnych z życia społecznego ${ }^{29}$. Pań-

${ }^{23}$ Tamże, s. 3-5.

${ }^{24}$ Zofia Łubieńska, s. Maria Cecylia (1874-1937), dr filozofii, nauczycielka, wychowawczyni, przełożona generalna urszulanek polskich, przełożona polskiej prowincji ss. urszulanek OSU; za poparciem metropolity krakowskiego, Adama Sapiehy, zorganizowała Wyższe Kursy Katechetyczne dla kobiet, prowadzone przez wybitnych ks. profesorów, które wykształciły katechetki zakonne i świeckie; doprowadziła do rozkwitu klasztory i szkoły urszulańskie w epoce międzywojennej. Por. Siostry zakonne w Polsce, red. K. Dębowska, J. Kłoczowski, D. Olszewski, A. Siewierska, Niepokalanów 1994, s. 172-176.

${ }^{25}$ Ludwika Dobrowolska, s. Maria Zenona od Zbawiciela (1879-1956), nauczycielka, wychowawczyni, przełożona generalna Zgromadzenia Sióstr Niepokalanego Poczęcia NMP w latach 1933-1953; przeniosła dom generalny z Jazłowca do Szymanowa k. Warszawy, podjęła starania o rozpoczęcie procesu beatyfikacyjnego założycielek zgromadzenia: Józefy Karskiej i Marceliny Darowskiej; jedna z inicjatorek porozumienia międzyzakonnego; weszła w skład pierwszej komisji porozumienia. Por. Siostry zakonne w Polsce, s. 64-67.

${ }^{26}$ Por. A.Z. Kotowska, Ch. Szarska, Urszulanki Unii Rzymskiej. Prowincja zakonu św. Urszuli w latach 1939-1947, w: Żeńskie zgromadzenia zakonne w Polsce 1937-1947, t. 12, Lublin 1998, s. 99; Łączka, Wspomnienia o współpracy międzyzakonnej, t. 1, s. 3-8.

${ }^{27}$ S. Emanuela Mrozowska (1897-1952), od 1937 r. przełożona prowincjalna polskiej prowincji Zgromadzenia Sióstr Urszulanek Unii Rzymskiej; ideę współpracy międzyzakonnej przejęła po swojej poprzedniczce s. Cecylii Łubieńskiej; od 1946 r. w składzie zarządu porozumienia międzyzakonnego, pierwsza przewodnicząca porozumienia. Por. Łączka, Wspomnienia o wspótpracy międzyzakonnej, t. 2, s. 344-347.

${ }^{28} \mathrm{Z}$ relacji s. K. Dębowskiej (na podst. rozmowy z autorką, styczeń 2013 r.).

${ }^{29}$ Przykładowe działania: upaństwowienie i likwidacje placówek charytatywnych, opiekuńczych i oświatowo-wychowawczych żeńskich zgromadzeń zakonnych; prawne i faktyczne odsunięcie żeńskich zgromadzeń zakonnych od pracy katechetycznej; wyrugowanie sióstr zakonnych ze szpitali; por. A. Mezglewski, Prawne i faktyczne formy dyskryminacji zgromadzeń zakonnych, w: Zakony żeńskie w PRL. Prawo instrumentem walki władz komunistycznych z Kościołem i zakonami 
stwo przejmowało na własność dzieła zgromadzeń ${ }^{30}$, a z osób konsekrowanych oczyszczało zakłady i miejsca pracy ${ }^{31}$. Uniemożliwiano zakonnicom zdobywanie, czy podnoszenie kwalifikacji zawodowych. Obowiązujące prawo, pozwalając na szeroką interpretację przepisu kodeksu karnego o działaniu na szkodę interesów $\mathrm{PRL}^{32}$, prowadziło do restrykcyjnych zachowań i zamykania Kościoła w jego własnych murach ${ }^{33}$. To samo odnosiło się do zakonów, które dotkliwiej odczuły zwiększającą się punitywność wymiaru sprawiedliwości.

Zamierzona przez państwo penalizacja działalności zakonów, powodowała wycofywanie się sióstr zakonnych z dotychczasowej aktywności, wywołując poważne zmiany jakościowe w samych instytutach. Odsunięcie od tradycyjnych prac było szczególnie ciężkim ciosem dla zgromadzeń żeńskich, które praktycznie traciły podstawy materialne, niezbędne do dalszej egzystencji.

$\mathrm{Na}$ domy zakonne, które coraz trudniej było utrzymać, nakładano wysokie podatki i grzywny ${ }^{34}$. Siostry nękano również wezwaniami na milicję lub do urzędu bezpieczeństwa oraz aresztowaniami ${ }^{35}$. Brutalizacja antyzakonnych posunięć, swój szczyt osiągnęła w przymusowej komasacji zakonnic, w utworzonych spe-

w Polsce, red. A. Mirek, Lublin 2009, s. 11-19; E. Kaczmarek, Dlaczego przeszkadzaty? Polityka władz partyjnych i rzadowych wobec żeńskich zgromadzeń zakonnych $w$ Polsce w latach 1945-1956, Warszawa 2007, s. 24-52.

${ }^{30} \mathrm{~W}$ latach 1949-1967 zlikwidowano 80 szkół zakonnych, 680 przedszkoli, 73 świetlice, 46 żłobków. Zob. Konferencja Wyższych Przełożonych Zakonów Męskich, Konferencja Wyższych Przełożonych Żeńskich Zgromadzeń Zakonnych. Życie konsekrowane w Polsce na poczattu nowego tysiąclecia, red. K. Wójtowicz, Kraków 2003, s. 72.

${ }^{31}$ Zob. np.: Archiwum Prowincjalne Zgromadzenia Sióstr Służebniczek NMP NP w Katowicach - Panewnikach, s. C Zarząd Prowincji II Przeł. prow. 2., Sprawozdania do Generalatu 19471964: „Podcięty został byt materialny Zgromadzenia, a przede wszystkim placówek. Zwolnione zostały prawie wszystkie siostry pielęgniarki z ośrodków zdrowia, z przedszkoli, a nawet częściowo z 2 szpitali. (...) Dyrekcja szpitala wypowiedziała siostrom mieszkanie służbowe, bez wskazania mieszkania zastępczego".

${ }^{32}$ Represje wobec osób duchownych i konsekrowanych $w$ PRL $w$ latach 1944-1989, red. A. Grześkowiak, Lublin 2004, 87-88.

${ }^{33}$ B. Skręta, Stosunki Państwo-Kościót w Polsce w latach 1944-1989, w: Kościót i religijność Polaków 1945-1999, red. W. Zdaniewicz, Warszawa 2000, s. 89.

${ }^{34}$ Zob. np.: Archiwum Generalne Sióstr Służebniczek NMP NP we Wrocławiu, Sprawozdania roczne prowincji opolskiej 1964-1970, s. B. IV 10 T I 2/Opole: „Prowincja nie posiada żadnych długów ani zobowiązań i jest w stanie utrzymać się samodzielnie. Na większości domów jednak spoczywają rzekome zobowiązania czynszowe, które dochodzą do poważnych sum. Na skutek tego w dalszym ciągu odbywają się egzekucje i domy te są w ciągłym zagrożeniu. W związku z tym, w większości wypadków, nie można przeprowadzić wymaganych remontów, ani zaopatrzyć je w potrzebne urządzenia".

${ }^{35} \mathrm{Na}$ przykład: przełożoną generalną służebniczek śląskich wezwano do Urzędu Wojewódzkiego we Wrocławiu, w którym otrzymała zarządzenie Prezydium Wojewódzkiej z dn. 31 lipca 1954 r. oraz zarządzenie wikariusza generalnego K. Lagosza o wysiedleniu sióstr i likwidacji domów. Przełożona generalna nie wyraziła zgody na wysiedlenie sióstr. Zob. Archiwum Prowincjalne Zgromadzenia Sióstr Służebniczek NMP NP w Leśnicy Opolskiej. Sprawy narodowościowe. Wezwanie do PWRN we Wrocławiu Nr W 13/46/54 z dn. 31 lipca 1954 r.; Odpis pisma PWRN we Wrocławiu nr W 3/46/54 z dn. 31 lipca 1954 r. do Przełożonej Generalnej. 
cjalnie dla nich, obozach pracy. W 1954 r. do obozów wywieziono 1.500 sióstr z 323 domów zakonnych z terenu województwa katowickiego, opolskiego i wrocławskiego. W latach 1954-1956 działało 8 obozów pracy dla sióstr: w Staniątkach (dwa), Stadnikach, Wieliczce, Dębowej Łące, Gostyniu Wielkopolskim i Kobylinie. Była to tzw. akcja o kryptonimie X2, w której najbardziej ucierpiały służebniczki śląskie ${ }^{36}$.

W Polsce, u podstaw porozumienia między zakonami - a w przyszłości powstania konferencji wyższych przełożonych żeńskich zgromadzeń zakonnych stała konieczność współpracy instytutów w budowaniu wspólnych struktur obronnych. Wspieranie zagrożonych w bycie zgromadzeń zakonnych, nowe ukierunkowanie ich aktywności oraz silniejsze powiązanie z Prymasem Wyszyńskim - to najbardziej charakterystyczne wyznaczniki żeńskiej współpracy międzyzakonnej w okresie PRL.

\section{Konferencja żeńska przed uznaniem kanoniczym}

Kształtowanie się konferencji wyższych przełożonych zgromadzeń zakonnych żeńskich w Polsce przechodziło przez kolejne etapy transformacji: 1) zawiązanie się w 1945 r. współpracy między zgromadzeniami żeńskimi w tzw. Porozumienie Międzyzakonne, działające pod kuratelą Prymasa Augusta Hlonda; 2) reorganizacja struktur współpracy między zakonami żeńskimi, dokonana przez Prymasa Wyszyńskiego i oficjalne utworzenie Ośrodka Międzyzakonnego w Warszawie w 1949 r.; 3) ściślejsze związanie zgromadzeń żeńskich z hierarchią Kościoła, przez powołanie w $1950 \mathrm{r}$. Wydziału Spraw Zakonnych, pełniącego rolę pośrednika między przełożonymi wyższymi zgromadzeń zakonnych a Prymasem Polski oraz podporządkowanie współpracy międzyzakonnej WSZ; 3) wydanie w $1960 \mathrm{r}$. norm regulujących współpracę przełożonych wyższych zgromadzeń żeńskich oraz prawne ustanowienie samodzielnego organu - konsulty.

\section{a. Porozumienie Międzyzakonne}

W pierwszych latach instalowania się władzy ludowej w Polsce, zasadniczo nie było jawnych wystąpień przeciw zgromadzeniom zakonnym, traktowanym zresztą dość instrumentalnie ${ }^{37}$. Spodziewano się jednak poważniejszego ataku na Kościół i podległe mu instytucje ${ }^{38}$. Z tego powodu, kard. August Hlond, ówczesny Prymas Polski, wsparty przez Stolicę Apostolską specjalnymi pełnomocnictwami do uporządkowania życia religijnego w kraju ${ }^{39}$, zorganizował 5 grudnia $1945 \mathrm{r}$. na Jasnej Górze spotkanie z wyższymi przełożonymi zgromadzeń zakonnych. Przestrzegał wówczas, że katolicyzmowi grozi rozprawa z bolszewizmem, który wy-

${ }^{36}$ Por. A. Mirek, Atlas żeńskiego ruchu zakonnego na ziemiach polskich $w$ XIX $i$ XX wieku, Lublin 2007, s. 28.

${ }^{37}$ Por. J. Żaryn, Dzieje Kościoła katolickiego w Polsce (1944-1989), Warszawa 2003, s. 75-81.

${ }^{38}$ Por. A. Hlond, Wielkopostny List pasterski Episkopatu Polski «O panowanie ducha Bożego w Polsce», w: Listy pasterskie Episkopatu Polski. 1945-2000, red. P. Libera, A. Rybicki, S. Łącki, t. 1, Marki 2003, s. 11-19; G. Bartoszewski, OFMCap, Sprawozdanie ze zjazdu wyższych przełożonych w Krakowie dn. 24 stycznia 1946 r., s. 1 (mps w posiadaniu autora).

${ }^{39}$ Por. J. Żaryn, Kościół w PRL, Warszawa 2004, s. 11; August Kardynał Hlond. Dzieła. Nauczanie 1897-1948, red. J. Konieczny, t. 1, Toruń 2003, s. 7. 
kazuje tendencję do zagarnięcia władzy na każdym odcinku życia. Nie chodzi o przetrwanie - nauczał - chodzi o zaktywizowanie sił katolickich, by nie tylko oprzeć się naporowi bezbożnictwa i niemoralności, lecz pokonać w organizmie narodowym truciznę i odzyskać pełne zdrowie. W tym powinny mieć swój udział zakony, które w przyszłości o tyle będą miały widoki, o ile teraz wykażą się ofiarnym wysiłkiem. Wielkie posłannictwo zakonów jest może największe w historii Polski ${ }^{40}$.

Podjęcie współdziałania wyższych przełożonych między sobą, jak również ściślejszej współpracy z władzą kościelną, stało się zadaniem pierwszoplanowym. W kronice ss. niepokalanek z Szymanowa pod datą 14 listopada 1945 r. znalazł się zapis: „W rozmowie z Ks. Kardynałem Matka Zenona Dobrowolska porusza konieczność porozumienia między zakonami dla jednolitego działania. Ksiądz Kardynał odpowiedział, że niedługo zwoła zjazd przełożonych generalnych i prowincjalnych wszystkich zakonów w Polsce" ${ }^{41}$.

W klasztorze ss. urszulanek w Krakowie, dn. 9 grudnia 1945 r., miało miejsce zebranie przedstawicielek dwunastu zgromadzeń żeńskich zajmujących się pracą wychowawczą. Podjęto wówczas decyzję o rozszerzeniu współpracy na wszystkie zgromadzenia oraz powołano faktycznie pierwszą konsultę wyższych przełożonych żeńskich zgromadzeń zakonnych, zwaną wówczas zarządem komisji dla porozumienia międzyzakonnego lub od liczby członkiń konsulty: Piątką. W jej skład wchodziły: s. Zenona Dobrowolska (niepokalanka), s. Pia Leśniewska (urszulanka SJK), s. Emanuela Mrozowska (urszulanka OSU), s. Wanda Żurawska (szarytka), p. Ludwika Ropp (przedstawicielka zgromadzeń bezhabitowych). Od 1949 r. zarząd poszerzył swój skład o dwie osoby (stąd przyjęła się nazwa tzw. Siódemki) i przedstawiał się następująco: s. Brygida Rodziewicz, przewodnicząca (urszulanka SJK), s. Emanuela Mrozowska, s. Zenona Dobrowolska, s. Beatrix Kirkor (nazaretanka), s. Wanda Żurawska, p. Ludwika Ropp, s. Immaculata Niezabytowska, skarbnik (niepokalanka) ${ }^{42}$. Zarząd pełnił funkcje kontrolną, przygotowywał szkolenia i zjazdy międzyzakonne. Przewodniczącą tak utworzonej komisji dla porozumienia międzyzakonnego została s. Emanuela Mrozowska ${ }^{43}$.

Na początku 1946 r. (w dn. 24-25 stycznia) odbył się w tym samym miejscu, zapowiedziany przez Prymasa A. Hlonda, zjazd wyższych przełożonych żeńskich zgromadzeń zakonnych ${ }^{44}$. Zgromadził 124 siostry z 53 zgromadzeń, w tym przełożone zakonów klauzurowych, które ks. Prymas mógł zaprosić na mocy specjalnych uprawnień Stolicy Apostolskiej. Podczas zjazdu, Prymas uwrażliwiał siostry

${ }^{40}$ G. Bartoszewski OFMCap, Rola siostry referentki zakonnej $w$ diecezji, Warszawa [b.m.w.], s. 2 (mps w posiadaniu autora).

${ }^{41}$ Tamże.

${ }^{42}$ Łączka, Wspomnienia o wspótpracy międzyzakonnej, s. 14, 29.

${ }^{43}$ Tamże.

4417 stycznia 1946 r. rozesłany został okólnik wzywający do Krakowa wyższe przełożone. Podczas spotkania siostrom nie wolno było prowadzić żadnych notatek. Zjazd zapamiętany został przez siostry, jako wspólny front zgromadzeń zakonnych wobec władz świeckich. Prymas tłumaczył przełożonym dążenia władz państowych oraz wskazywał, jak się przed nimi bronić. Łączka, Wspomnienia o wspótpracy międzyzakonnej, t. 1, s. 14. 
przełożone, na zagrożenia Kościoła i życia zakonnego w Polsce. Zapowiadał najcięższe starcie i dawał do zrozumienia, że urzędy państwowe będą gromadziły szczegółowe dane o zakonach. Podejmą starania, by obciążyć i zdyskredytować zgromadzenia w oczach społeczeństwa. Zalecał ostrożność w przyjmowaniu kandydatek ${ }^{45}$.

Wykształcone struktury porozumienia miedzy zakonami żeńskimi, jeszcze w czasie urzędowania ks. Prymasa A. Hlonda, pozwoliły na podjęcie pierwszych prób wspólnego rozwiązania niecierpiących zwłoki problemów. Chodziło zwłaszcza o zawodowe wykształcenie zakonnic ( $50 \%$ bez odpowiednich kwalifikacji), w szczególności kształcenie pielęgniarek i katechetek, organizację kursów wakacyjnych dla wychowawczyń internatów, organizację kursów społeczno-pedagogicznych dla dyrektorek i kierowniczek szkół średnich, podstawowych i internatów ${ }^{46}$. Uporządkowania wymagały również inne tematy: współpraca zgromadzeń żeńskich z kościelną organizacją charytatywną Caritas, trudności finansowe, poziom formacji duchowej i intelektualnej sióstr, kontakty sióstr z osobami świeckimi. Zredagowany został okólnik komisji międzyzakonnej, skierowany do wyższych przełożonych o wprowadzeniu tzw. kwartalnego dnia pokuty we wszystkich zgromadzeniach żeńskich (w tym czasie w Polsce było 90 zgromadzeń żeńskich $)^{47}$.

Zjazdy przełożonych wyższych miały również charakter szkoleniowy. Prelegentami, którzy w tym okresie swoją wiedzą i kompetencją, wspierali zjazdy wyższych przełożonych żeńskich zgromadzeń zakonnych, byli m.in.: bp lubelski Stefan Wyszyński (zagadnienia społeczne), o. Bernard Przybylski, dominikanin (apostolstwo), o. Jan Wierusz Kowalski, benedyktyn (liturgia), ks. Bronisław Dąbrowski (problematyka prawna), a także o. Tomasz Rostworowski, jezuita i s. Jana Płaska, urszulanka SJK. Podczas zjazdów, przełożone wyższe prowadziły dyskusje nad najbardziej pilnymi dla zgromadzeń zagadnieniami: uczciwość w prowadzeniu rachunków (s. Jozafata Szeptycka), konieczność kształcenia katechetek (s. Alozja Bańkowska), kształcenie pielęgniarek (s. Pia Leśniewska) ${ }^{48}$.

Ks. Prymas A. Hlond, sam zakonnik, wspierał wyższych przełożonych, tak żeńskich, jak i męskich zgromadzeń ${ }^{49}$, a kierując współpracą międzyzakonną, po-

${ }^{45}$ Sprawozdanie ze zjazdu wszystkich zakonów w Polsce zwołanego przez Jego Eminencję księdza kardynała Prymasa Augusta Hlonda w Krakowie dn. 24 stycznia 1946 roku, s. 3 (mps w posiadaniu G. Bartoszewskiego).

${ }^{46}$ Np. w Szymanowie zorganizowano kurs w dn. 17-22 lipca 1947, w którym wzięło udział 140 sióstr z różnych zgromadzeń. Prelegentami byli:dominikanin Bernard Przybylski, ks. bp Stefan Wyszyński, benedyktyn o. Wieriusz Kowalski . Zob. Łączka, Wspomnienia o wspótpracy międzyzakonnej, t.1, s. 17.

${ }^{47}$ Tamże, s. 17-18.

${ }^{48}$ Tamże, s. 16.

${ }^{49} \mathrm{Za}$ życia kard. A. Hlonda zorganizowanych zostało kilka spotkań wyższych przełożonych zgromadzeń męskich. Na zawiązanie się międzyzakonnej współpracy męskiej zasadniczy wpływ miała również sytuacja polityczna, a także wynikający z niej przez długi okres, brak żywszego kontaktu z przełożonymi generalnymi, rezydującymi za granicą. Por. Bar, Konferencje Wyższych Przetożonych, s. 101; Zamiatała, Konferencja Wyższych Przełożonych Zakonów Męskich, s. 323-324. 
twierdzał sformułowaną wcześniej tezę, że komunizm w Polsce napotka zwarty front Kościoła ${ }^{50}$.

Zaistniała potrzeba tworzenia przedstawicielstw zakonów żeńskich dla mniejszych jednostek administracyjnych. W związku z tym, od 1946 r. zarysowały się zręby współpracy międzyzakonnej na poziomie diecezjalnym. Największa aktywność wspólnych działań zauważalna była na terenach diecezji: częstochowskiej, kieleckiej, krakowskiej, lubelskiej, tarnowskiej, warszawskiej, wileńskiej ${ }^{51}$ i wrocławskiej. Polegała na organizowaniu regionalnych zebrań wyższych przełożonych, wymianie informacji, szkoleniach i omawianiu wspólnej postawy wobec działań wyznaniowych państwa. Podejmowano starania, by zjazdy nie zwracały uwagi nieprzychylnych władz świeckich ${ }^{52}$.

\section{b. podporządkowanie Wydziałowi Spraw Zakonnych}

Po objęciu funkcji Prymasa Polski przez biskupa lubelskiego Stefana Wyszyńskiego, żeńska współpraca międzyzakonna była kontynuowana. Władze państwowe konstatowały: „Zakony zostały (...) wprzęgnięte w politykę kard. Wyszyńskiego i Episkopatu. Stały się awangardą kościoła walczącego politycznie i ideologicznie z państwem ludowym"53. Przystąpiono więc szybko do ataku na życie konsekrowane w Polsce, kontrolowano jego działalność, liczebność oraz dążono do powstrzymania ekspansji zgromadzeń ${ }^{54}$.

Prymas Wyszyński, dostrzegając zagrożenie zgromadzeń zakonnych w Polsce, przekształcił dotychczasowe formy Porozumienia Międzyzakonnego, powołując oficjalnie we wrześniu 1949 r., Ośrodek Międzyzakonny w Warszawie ${ }^{55}$. Warszawski Ośrodek miał już swoją tradycję, w związku z organizowaniem zjazdów Komisji Międzyzakonnej, tzw. Piątki, które odbywały się u ss. urszulanek SJK przy ul. Wiślanej w Warszawie. W 1949 r. Prymas Wyszyński na przewodniczącą Ośrodka wyznaczył s. Beatrix Kirkor, nazaretankę. Na prośbę Prymasa Wyszyńskiego o oddelegowanie do pracy w Ośrodku sióstr, przełożone wyższe podczas wspólnego posiedzenia wyznaczyły: s. Konstantynę Baranowską, urszulankę

${ }^{50}$ Sprawozdanie ze Zjazdu wszystkich Zakonów w Polsce, s. 2.

${ }^{51}$ Po II wojnie światowej z zachodniej części archidiecezji wileńskiej, która znajdowała się na terytorium polskim, utworzono administrację apostolską w Białymstoku. Dopiero w 1992 r., papież Jan Paweł II bullą Totus Tuus Poloniae Populus, ustanowił archidiecezję białostocką.

${ }^{52}$ Łączka, Wspomnienia o wspótpracy międzyzakonnej, t. 1, s. 19-20.

${ }^{53}$ AAN, UdSW, sygn. 133/14, Notatka informacyjna dot. działalności zakonów w Polsce, k. 1.

${ }^{54}$ „Dzięki temu, że działalność zakonów nie była kontrolowana przez państwo oraz przy zachowaniu dużych przywilejów (...) zakony w Polsce zaczęły szybko się rozwijać liczebnie. Ponadto: Zakony w kościele katolickim wykonywały i wykonują najbardziej odpowiedzialne funkcje (..) oraz używane są do zadań na tych odcinkach, na których kler diecezjalny często zawodzi. Gruntowane przygotowanie zakonników w nowicjatach i seminariach zakonnych predestynuje ich do tych zadań, których wykonanie wymaga ślepego posłuszeństwa (ślub posłuszeństwa), fanatyzmu religijnego, konserwatyzmu i wrogości do tego, co postępowe". AAN, UdSW, sygn. 133/14, Notatka informacyjna dot. działalności zakonów w Polsce, k. 1.

${ }^{55}$ Łączka, Wspomnienia o wspótpracy międzyzakonnej, s. 26. Nazwa: Porozumienie Międzyzakonne była jednak nadal używana, nawet przez Prymasa Wyszyńskiego. S. Wyszyński, Pro memoria. Zapiski z lat 1948-1949 i 1952-1953, Warszawa 2007, s. 281. 
OSU oraz s. Zofię Andrzeję Wysokińską, urszulankę SJK ${ }^{56}$.

W tym okresie, przełomowym wydarzeniem dla współpracy wyższych przełożonych żeńskich zgromadzeń zakonnych, było utworzenie w 1950 r. Wydziału Spraw Zakonnych, który stał się jednostką organizacyjną Sekretariatu Prymasa Polski ${ }^{57}$. Powstałemu Wydziałowi podporządkowany został cały dotychczasowy dorobek współpracy międzyzakonnej wyższych przełożonych żeńskich zgromadzeń zakonnych, nie wyłączając nowopowstałego Ośrodka. Konsulta (komisja międzyzakonna) utraciła swoją dotychczasową pozycję koordynatora żeńskiej współpracy międzyzakonnej. Prymasowi Wyszyńskiemu zależało jednak na utrzymaniu konsulty, która pełnić miała odtąd rolę organu doradczego ks. Prymasa. Prymas Wyszyński oświadczył bowiem, że choć Stolica Apostolska poddała pod jego kompetencje sprawę zakonów w Polsce, nie chce podejmować decyzji, które dotyczą zgromadzeń zakonnych, bez ich udziału i opinii. Konsulta (komisja międzyzakonna) działała więc nadal, w porozumieniu z ks. Prymasem i WSZ, wysuwając postulaty, podejmowane podczas spotkań z ks. Prymasem oraz zebrań plenarnych wyższych przełożonych żeńskich zgromadzeń zakonnych realizowanych w formie zjazdów ${ }^{58}$.

${ }^{56}$ Siostry zakonne, które rozpoczynały pracę Ośrodka Międzyzakonnego to: s. Beatrix Kirkor, nazaretanka (ur. 1895, zm. 1985; od 1948 r. przełożona prowincjalna warszawskiej prowincji ss. nazaretanek, we wrześniu 1949 r. mianowana przez Prymasa Wyszyńskiego na przewodniczącą Ośrodka Międzyzakonnego w Warszawie, w 1952 r. aresztowana w związku z procesem ordynariusza kieleckiego ks. bp Cz. Kaczmarka, uwolniona w listopadzie 1953 r.); s. Konstantyna Baranowska, urszulanka OSU (ur. 1910, pracowała bardzo krótko w Ośrodku Międzyzakonnym - do lipca 1950 r.); s. Zofia Andrzeja Wysokińska, urszulanka SJK (ur. 1910, zm. 1997; w Ośrodku M. od 1949 r., objęła w nim tzw. referat ideowy, odwiedzała Prymasa Wyszyńskiego więzionego w Komańczy, zachowało się 16 listów z Komańczy napisanych przez ks. Prymasa do s. Zofii; z wielkim poświęceniem prowadziła pracę biurową Ośrodka w trudnych warunkach, zaangażowana w pracę nad powstawaniem pierwszych biuletynów zakonnych, referatów z kursów, dni skupienia itp.); s. Adela Łączka, urszulanka OSU (ur. 1915, zm. 1998; w 1. 1950-57 pracowała w Wydziale Spraw Zakonnych, w 1955 r. odwiedziła Prymasa Wyszyńskiego w Komańczy, w 1954 i 1955 odwiedziła siostry internowane w obozach pracy, autorka dwutomowych Wspomnień o wspótpracy międzyzakonnej zgromadzeń żeńskich w Polsce po II wojnie światowej). Por. E. Wajs, Oni kładli fundamenty, w: „Biuletyn KWPŻZZ”, 6, (1998) s. 46-47; Kaczmarek, Dlaczego przeszkadzały, s. 132; Łączka, Wspomnienia o wspótpracy międzyzakonnej, t. 2, s. 62-70.

${ }^{57}$ Bar, Konferencje Wyższych Przełożonych, s. 102.

${ }^{58}$ A. Łączka, Wspomnienia o wspótpracy międzyzakonnej, t. 2, s. 82-83. Na pytanie: czy konsulta żeńska mogła samodzielnie działać i czy takie podporządkowanie wyższych przełożonych Prymasowi było rzeczywiście konieczne - s. Krystyna Dębowska, franciszkanka od cierpiących (w 1983 r. mianowana przez Prymasa Wyszyńskiego konsultorką, ob. przewodnicząca Komisji ds. Życia Konsekrowanego KWPŻZZ), uzasadniła konieczność podporządkowania zakonów Prymasowi i WSZ: 1) sytuacją polityczną kraju, która wymagała silnej centralizacji działań w Kościele; 2) poważnym zróżnicowaniem w samych żeńskich zgromadzeniach zakonnych, które potrzebowały silnego autorytetu i władzy zewnętrznej oraz odgórnych postanowień, zmierzających do podniesienia i wyrównania przede wszystkim poziomu formacyjnego i intelektualnego w poszczególnych instytutach. Dotychczasowe różnice nie pozwoliłyby na efektywne zaangażowanie - w skali ogólnopolskiej - zgromadzeń żeńskich, w pracę konferencji i konsulty (na podst. rozmowy z s. K. Dębowską, styczeń 2013 r.). 
Ogólnopolskie spotkania wyższych przełożonych, odbywały się najczęściej na Jasnej Górze lub w warszawskich domach zakonnych, pod nazwą: dni skupienia lub pielgrzymki (nazwy zastępcze miały ukryć przed władzami świeckimi prawdziwy cel spotkań). Zjazdy wyższych przełożonych poświęcone były wspólnej modlitwie, ale i dokształcaniu oraz wymianie informacji ${ }^{59}$. Pełniły istotną rolę w realizacji wyznaczonych zadań międzyzakonnych. Pieczołowicie przygotowywane spotkania o charakterze instruktażowo-formacyjnym, zawierały: wystąpienia programowe Prymasa Wyszyńskiego, elementy szkolenia wyższych przełożonych z zakresu prawa, teologii, ascetyki. Wykłady prowadzili między innymi: ks. B. Dąbrowski, ks. J. Jaroszewicz, bp A. Pawłowski, bp K. Kowalczyk, bp B. Kominek, o. T. Rostworowski, o. K. Hołda, o. B. Przybylski ${ }^{60}$. Podczas jasnogórskich szkoleń, wyższe przełożone edukowane były odnośnie sytuacji Kościoła powszechnego $\mathrm{w}$ świecie i w Polsce. Ważnym punktem zjazdów były ponadto sprawozdania z przeprowadzonych przez zakony żeńskie akcji i zrealizowanych zadań programowych ${ }^{61}$.

Prymas Wyszyński zauważał, że początek współpracy rodzin zakonnych w tym okresie, budził wiele obaw, nawet wśród samych instytutów żeńskich, które nie chciały utracić, gwarantowanej im przez Kościół, autonomii. Jako rzeczywistą przyczynę niechęci, Prymas Wyszyński podawał jednak indywidualizm poszczególnych zgromadzeń, brak szerszego spojrzenia i więzi z Kościołem powszechnym, małoduszność, brak świadomości zagrożeń, podwórkowość życia ${ }^{62}$. Opory stawiali również biskupi, obawiając się, że taka forma współpracy międzyzakonnej, z silnie scentralizowaną władzą, skupioną w rękach Prymasa, ograniczy z kolei ich władzę pasterską na terenie diecezji. Protestowały zgromadzenia zakonne męskie ${ }^{63}$. $Z$ tego powodu praca - w początkowym stadium porozumienia szła bardzo powoli. Ostatecznie, Prymas Wyszyński przyznawał jednak, że doświadczenie współdziałania, poważnie umocniło życie konsekrowane w całości oraz poszczególne instytuty żeńskie i podniosło autorytet przełożonych wyższych $^{64}$.

Skutki współpracy konsulty z Prymasem Wyszyńskim i Wydziałem Spraw Zakonnych, spotkały się z czasem z dużym uznaniem wśród samych zgromadzeń zakonnych. Siostry pracujące w Ośrodku Międzyzakonnym, prowadziły przede wszystkim, szczególnie potrzebny w tym czasie, instruktaż dla zgromadzeń żeńskich i zakonnic z całej Polski: jak się należy zachować i jakie przyjąć postawy wobec przedstawicieli władz państwowych. Zebrane przy okazji spotkań z sio-

${ }^{59}$ Bar, Konferencje Wyższych Przełożonych, s. 109. Kierowane do przełożonych wyższych wykłady ks. abpa B. Dąbrowskiego, związane z nurtem odnowy życia zakonnego Soboru Watykańskiego II, znaleźć można w: B. Dąbrowski, Instaurare omnia in Christo, Warszawa 1987, przykładowo: s. 26-35 (kwiecień 1964); s. 44-53 (maj 1965); s. 54-62 (kwiecień 1967).

${ }^{60}$ APP, Pielgrzymka Przełożonych Wyższych Zgromadzeń Zakonnych Żeńskich na Jasnej Górze, dn. 8-10 października 1957 r., w: Konsulta, b.p.

${ }^{61}$ Tamże.

${ }^{62}$ APP, Pro memoria z dn. 12 maja 1959 r., w: „Konsulta”, b.p.

${ }^{63}$ Łączka, Wspomnienia o wspótpracy międzyzakonnej, t. 1, s. 44.

${ }^{64}$ AIP, S. Wyszyński, List do Sióstr. Komańcza, dn. 12 lipca 1956, w: Przemówienia, t. 1, s. 1. 
strami informacje i pisma urzędowe dot. relacji z władzami świeckimi, dostarczane były najpierw Prymasowi, a następnie biskupowi Zygmuntowi Choromańskiemu, jako rzeczowa dokumentacja, będąca podstawą do interwencji u czynników państwowych, w ramach tzw. Komisji Mieszanej ${ }^{65}$.

Dzięki pomocy ks. Prymasa, zgromadzenia zakonne żeńskie, cieszyły się znaczącym wsparciem oraz opieką hierarchii i polskiego duchowieństwa ${ }^{66}$. Biskupowi Zygmuntowi Choromańskiemu do prowadzenia spraw zakonnych, Prymas przydzielił ks. Bronisława Dąbrowskiego, późniejszego arcybiskupa, który został mianowany pierwszym dyrektorem Wydziału Spraw Zakonnych ${ }^{67}$ (następnie urząd dyrektora Wydziału pełnili ks. Alojzy Żuchowski, pallotyn oraz ks. Józef Dąbrowski, również pallotyn ${ }^{68}$ ). Istotną pomocą było również zaangażowanie ks. Antoniego Baraniaka, salezjanina, z czasem arcybiskupa poznańskiego. Jednym z pierwszych zadań zrealizowanych przez Ośrodek Międzyzakonny z polecenia Prymasa, było sporządzenie przez m. Konstantynę Baranowską oraz Ligię Malinowską, pierwszego katalogu z danymi dot. zgromadzeń zakonnych w Polsce ${ }^{69}$.

Cele współpracy żeńskiej konsulty z władzami kościelnymi były w tym okre-

${ }^{65}$ Łączka, Wspomnienia o wspótpracy międzyzakonnej, t. 1, s. 27.

${ }^{66} \mathrm{~Np}$. przełożona generalna służebniczek śląskich wymienia i szczegółowo opisuje formy pomocy udzielane zgromadzeniu przez abpa B. Dąbrowskiego, jakimi były: obrona bytu i działalności zgromadzenia na Ziemiach Zachodnich; w okresie stalinizmu; obrona domu prowincjalnego w Katowicach-Panewnikach, pomoc w formacji duchowej i zawodowej sióstr, w przeprowadzeniu odnowy soborowej, wspieranie inicjatyw apostolskich i misyjnych zgromadzenia, pomoc w otworzeniu domów zakonnych w archidiecezji warszawskiej, troska o siostry zagranicą, popieranie dążeń federacyjnych czterech gałęzi ss. służebniczek. Zob. G. Gruszka, Ks. Arcybiskup Bronisław Dąbrowski w historii Zgromadzenia Sióstr Stużebniczek NMP śląskich, Wrocław 1987, s. 3-4 (mps w bibliotece w domu prowincjalnego służebniczek śląskich w Warszawie).

Relacje przełożonych wyższych, wchodzących w skład konsulty z kościelną hierarchią, były przedmiotem stałego monitoringu prowadzonego przez przedstawicieli władz państwowych. Zob. np. AAN, UdSW, sygn. 33/315, Poufna informacja Prezydium WRN w Poznaniu dla Urzędu do Spraw Wyznań, k. 4-6.

${ }^{67}$ Abp Bronisław Dąbrowski (1917-1997) - orionista, w 1950 r. powołany do pracy w biurze Sekretarza Episkopatu, w tym samym roku mianowany dyrektorem Wydziału Spraw Zakonnych, w 1962 r. konsekrowany na biskupa pomocniczego, w 1982 otrzymał godność arcybiskupa; w 1. 1969-1993 pełnił urząd sekretarza Episkopatu, w 1993 r. odznaczony przez prezydenta RP Lecha Wałęsę Krzyżem Komandorskim z Gwiazdą Orderu Odrodzenia Polski. Ponadto: członek Kongregacji Stolicy Apostolskiej dla Zakonników i Instytutów Świeckich, następnie Kongregacji Instytutów Życia Konsekrowanego i Stowarzyszeń Życia Apostolskiego, przewodniczący Komisji Episkopatu Polski ds. zakonnych, członek Komisji Maryjnej Episkopatu, członek Komisji Wspólnej Episkopat - Rząd PRL i RP. Jeden z najbliższych i najbardziej zaufanych współpracowników kard. Stefana Wyszyńskiego. Por. K. Dębowska, Wspomnienie o ks. arcybiskupie Bronisławie Dąbrowskim. Wystapienie podczas 117. Zebrania plenarnego KWŻZZ, Warszawa 2009 (mps w posiadaniu autorki); Noty biograficzne, w: Wyszyński, Pro memoria, s. 631; B. Łoziński, Leksykon zakonów w Polsce. Informator o życiu konsekrowanym, Warszawa 1998, s. 17.

${ }^{68}$ Dębowska, Referat wygłoszony podczas Konferencji Plenarnej KWPŻZZ, s. 4.

${ }^{69}$ Według katalogu na terenie Polski w 1949 było: 2488 domów zakonnych, 87 szkół z internatem, 95 burs i internatów, 263 domy dziecka, 680 przedszkoli, 73 świetlice, 46 żłobków, 18 zakładów specjalnych dla dzieci, 11 zakładów specjalnych dla dorosłych, 206 domów opieki dla 
sie zbliżone do wytyczonych jeszcze za urzędowania Prymasa Hlonda, a więc: organizowanie wspólnej linii obronnej żeńskich zgromadzeń zakonnych przed władzami państwowymi oraz podnoszenie poziomu życia zakonnego sióstr w Polsce ${ }^{70}$. Zaplanowana na skutek porozumienia Prymasa Wyszyńskiego z przełożonymi wyższymi żeńskich zgromadzeń zakonnych, ogólnopolska akcja szkoleniowa obejmowała: przełożone wyższe, przełożone lokalne, mistrzynie nowicjatów, ekonomki domów głównych, dyrektorki, nauczycielki, wychowawczynie szkół zakonnych, siostry parafialne, kapelanów i spowiedników zakonnic ${ }^{71}$. Szczególne osiągnięcia w tym zakresie to: utworzenie dla sióstr specjalnych studiów międzyzakonnych: Diecezjalnego Instytutu Katechetycznego (1950) w Krakowie oraz Wyższego Instytutu Katechetycznego (1951) ${ }^{72}$, Międzyzakonnego Studium Prawno-Administracyjnego w Częstochowie, Studium Muzyczno-Liturgicznego w Międzylesiu (1951) oraz Aninie, Studium Społeczno-Prawnego w Lublinie $(1953)^{73}$. Nałożony na siostry w Polsce, obowiązek poszerzania podstawowej wiedzy religijnej, traktowany był w żeńskich zgromadzeniach zakonnych jako wotum dziękczynne dla Matki Bożej Jasnogórskiej. Dokształcanie religijne przeprowadzone w latach 1952-1957, odbywało się według programu przygotowanego przez Wydział Spraw Zakonnych. Obejmowało katechizm, Stary i Nowy Testament, liturgikę i historię Kościoła. Zwracano prócz tego uwagę na właściwą formację duchową i moralną zakonnic, czego wyrazem była stała troska Prymasa Wyszyńskiego o należyty dobór i przygotowanie spowiedników oraz kierowników duchowych dla instytutów żeńskich ${ }^{74}$. Wyższe przełożone podjęły zalecenia Prymasa, by konsulta żeńska nawiązała współpracę z konsultą męską w sprawie udostępnienia żeńskim zgromadzeniom zakonnym spowiedników, rekolekcjonistów, prelegentów na konferencje i szkolenia międzyzakonne ${ }^{75}$.

dorosłych, 213 różnych innych placówek: stołówek, ośrodków zdrowia, prowadzonych kursów, 276 szpitali i sanatoriów. Łączka, Wspomnienia o wspótpracy międzyzakonnej, t. 1, s. 29.

${ }^{70}$ Wyszyński, Pro memoria, s. 104; 135; 235; 514.

${ }^{71}$ Łączka, Wspomnienia o wspótpracy międzyzakonnej, t. 1, s. 44. Relacje ze szkoleń i uczestnictwa sióstr w zjazdach formacyjnych oraz postulaty z tym związane, przekazywane były ks. Prymasowi. Zob. np. APP, Sprawozdanie z dnia skupienia przełożonych wyższych żeńskich stanów doskonałości z dn. 19 maja 1960 r., Warszawa, w: „Konsulta”, b.p.

${ }^{72}$ DIK powołał kard. A. Sapieha, a prowadzony był przez siostry urszulanki OSU. WIK przeznaczono dla sióstr ze świadectwem maturalnym. Główny cel WIK to umożliwienie siostrom zdobycia wyższych kwalifikacji, uprawniających do nauczania religii młodzież, a także do prowadzenia bardziej kompetentnej pracy formacyjnej we własnych zgromadzeniach. AAN, UdSW, sygn. 33/315, Sprawozdanie z przeprowadzonej wizytacji w domu zakonnym zgromadzenia ss. urszulanek w Krakowie, k. 12-14.

${ }^{73}$ Udział sióstr w szkoleniach, kursach i studium dokumentują m.in. sprawozdania roczne poszczególnych zgromadzeń zakonnych żeńskich, np.: Archiwum Generalne Służebniczek Wrocław, s.B. IV 10 T I 2/Opole, Sprawozdania roczne prowincji opolskiej 1964-1970: informacja o kształceniu sióstr m.in.: na WIK, studium administracyjno-prawnym, studium muzycznym, kursach katechetycznych, kursach opiekunek parafialnych, organistek, instruktorek duszpasterstwa młodzieży żeńskiej, maszynopisania, żywienia, kucharskim, pielęgniarskim.

${ }^{74}$ Wyszyński, Pro memoria, s. 395.

${ }^{75}$ Łączka, Wspomnienia o współpracy międzyzakonnej, t. 2, s. 97. 


\section{c. regulacje prawne z 1960 r.}

Podczas spotkań konsulty żeńskiej z Prymasem Wyszyńskim powracał temat statutu żeńskiej współpracy międzyzakonnej oraz statusu samej konsulty ${ }^{76}$. Zainteresowanie prawnym uregulowaniem dotychczasowej pracy, wzmacniane było sugestiami międzynarodowych kongresów zakonnych w Rzymie. W efekcie doszło do zatwierdzenia przez Prymasa Wyszyńskiego Norm regulujących pracę międzyzakonną żeńskich stanów doskonałości w Polsce (2 maja 1960 r. $)^{77}$ oraz dekretu ustanawiającego konsultę żeńską (4 czerwca 1960 r. $)^{78}$.

Normy, choć za swoją podstawę uznawały dekret Salutaris, podporządkowały jednocześnie pracę międzyzakonną Prymasowi, w związku z jego specjalnymi pełnomocnictwami nadanymi przez Stolicę Apostolską (art. 1). Podawały cel ogólny, za jaki uznano współpracę instytutów z hierarchią Kościoła w odnowieniu życia zakonnego i apostolatu (art. 2). Wyliczały ponadto zadania szczegółowe: 1) zapoznawanie się ze wskazaniami Stolicy Apostolskiej i Episkopatu; 2) omawianie problemów życia zakonnego, opracowywanie i realizacja wspólnych postulatów; 3) uzgadnianie wspólnego stanowiska w wystąpieniach na zewnątrz; 4) wymianę doświadczeń; 5) uzgadnianie akcji budzenia powołań oraz uświadamianie społeczeństwa o życiu zakonnym; 6) poszukiwanie sposobów skutecznego włączania się w duszpasterską pracę Kościoła (art. 3).

Normy uściślały metody pracy międzyzakonnej, za które uważały: 1) konsultę; 2) sekcje międzyzakonne; 3) dni skupienia - faktycznie zebrania plenarne. Skład dziesięcioosobowej konsulty wskazywał Prymas, z kandydatek wybranych podczas zebrania plenarnego ${ }^{79}$. Konsultorki ze swojego grona wybierały prze-

${ }^{76}$ Tamże, s. 86 i 90 .

${ }^{77}$ Archiwum Wydziału Spraw Zakonnych, Normy regulujące pracę międzyzakonną żeńskich stanów doskonałości w Polsce, z dn. 2 maja 1960 r. Dla porównania: współpraca zgromadzeń męskich została zreformowana przez Prymasa w 1957 r., który powołał konsultę WPZM działającą w oparciu o zatwierdzony przez niego w 1958 r. statut. Dokument definiował konferencję jako wzajemne porozumienie wyższych przełożonych, bez władzy zwierzchniej nad zakonami w Polsce (art. 2). Celem KWPZM miało być pogłębianie wiedzy o życiu zakonnym zawartej w dokumentach Kościoła, ustalanie wspólnej linii postępowania, uświadamianie społeczeństwa o zadaniach i wartościach życia zakonnego oraz ochrona i reprezentowanie interesów zgromadzeń męskich wobec władz kościelnych i świeckich, wymiana doświadczeń (art. 3). KWPZM prowadzić swoje prace miała w oparciu o: konsultę, komisje, zebrania plenarne, referenta konferencji. Powołano cztery komisje: wychowania i karności, studiów zakonnych, apostolstwa i duszpasterstwa, prawno-administracyjną (art. 4). KWPZM choć przeorganizowana nie posiadała jednak autonomii. Główną rolę odgrywał w niej mianowany przez Prymasa referent konferencji, który był pracownikiem Wydziału do Spraw Zakonnych. Dekretem rzymskiej Kongregacji do Spraw Zakonów z dn. 30 listopada 1963 r., KWPZM uzyskała osobowość prawną i zatwierdzenie nowego statutu. Statut przyznawał KWPZM w Polsce, całkowitą autonomię, nie był jednak w praktyce stosowany, nadal kierowano się statutem zatwierdzonym przez Prymasa Polski. Por. J. Bar, Konferencje wyższych przełożonych, s. 104-105.

${ }^{78}$ APP, Dekret ustanawiający Konsultę Wyższych Przełożonych Zakonów Żeńskich, z dn. 4 czerwca 1960 r., „Konsulta”, b.p.

${ }^{79} \mathrm{~W}$ tym okresie w zgromadzeniach męskich podobnie: konsulta w liczbie 5 członków wybierana była przez Prymasa z grona kandydatów wskazanych przez konferencję wyższych prze- 
wodniczącą, do której zadań należało reprezentowanie żeńskich stanów doskonałości wobec Prymasa Polski. Konsulta wybierana na okres 3 lat, pełniła funkcję organu doradczego Prymasa Polski. Uchwały podjęte podczas zebrań plenarnych, odbywających się dwa razy w roku, obowiązywały wszystkie zgromadzenia w Polsce dopiero po zatwierdzeniu przez Prymasa (art. 4). Normy wskazywały na koordynującą rolę Wydziału do Spraw Zakonnych, w sprawach dotyczących współpracy między zgromadzeniami. Mówiły o mianowanej przez Prymasa referentce, podporządkowanej Wydziałowi Spraw Zakonnych. Na poziomie diecezji normy regulowały pracę referentek diecezjalnych, zależnych od dyrektora Wydziału, a mianowanych przez Prymasa na wniosek miejscowych ordynariuszy $(\text { art. } 5)^{80}$.

Z kolei dekret ustanawiający żeńską konsultę, wydany został w tym samym roku, w trosce o rozwój wewnętrzny zgromadzeń zakonnych żeńskich oraz z konieczności dostosowania instytutów żeńskich do współczesnych wymagań Kościoła. Dokument zawierał informację o doradczym charakterze instytucji konsulty. Ponadto wymieniał konsultorki, ustanowione na okres trzech lat. W skład konsulty weszły: s. Franciszka Popiel (urszulanka SJK), s. Benedykta Woyczyńska (franciszkanka służebnica Krzyża), s. Bolesława Broda (boromeuszka), s. Małgorzata Piątkowska (nazaretanka), s. Stefania Barwińska (szarytka), s. Aniela Prendowska (felicjanka), s. Maria Piller (ss. Sługi Jezusa), s. Janina Wizor (ss. NotreDame), s. Bronisława Bzowska (wizytka) ${ }^{81}$.

Nadanie norm i wydanie dekretu ustanawiającego żeńską konsultę, nie było bynajmniej równoznaczne z powołaniem samodzielnej konferencji przełożonych wyższych zgromadzeń żeńskich. Trudna sytuacja sióstr w PRL, pozbawienie zakonów żeńskich środków materialnych, koniecznych do funkcjonowania i prowa-

łożonych. Konsultorzy sami spośród siebie wybierali przewodniczącego, którego jednak musiał zatwierdzić Prymas. Por. Archiwum Konferencji Wyższych Przełożonych Zgromadzeń Męskich, Ramowy Statut Konferencji Wyższych Przełożonych Zakonów Męskich w Polsce z dn. 15 kwietnia 1958 r., art. IV. pkt. 1, b. p. (podobnie: statut z 25 marca 1963 r.).

${ }^{80}$ AWSZ, Normy regulujące pracę międzyzakonną; Bar, Konferencje wyższych przełożonych zakonnych, s. 110-111.

${ }^{81}$ APP, Konsulta Wyższych Przełożonych Zakonów Żeńskich od 1957-1983, nr 123, b.p. Przed następnymi wyborami konsulty, szczegółowo omawiane były procedury głosowania i wyborów. APP, Omówienie techniki wyborów do konsulty, Jasna Góra, dn. 30 kwietnia 1963 r., „Konsulta”, b.p.

Składy konsulty do czasu kanonicznego erygowania konferencji (1970 r.) przedstawiały się następująco: od 1963 r. konsultorkami zostały: s. Franciszka Popiel, s. Aniela Prendowska, s. Janina Wizor, s. Stefania Barwińska, s. Zofia Szulc (zmartwychwstanka), s. Maria Piller, s. Helena Kania (franciszkanka Rodziny Maryi), s. Inez Strzałkowska (nazaretanka), s. Karmela Stępień (karmelitanka bosa). APP, „Konsulta”, Dekret Prymasa Polski z 30 maja 1963 r. Skład konsulty od 1966 r.: s. Aniela Prendowska, s. Inez Strzałkowska, s. Janina Wizor, s. Andrzeja Górska, s. Zbigniewa Jaworska (urszulanka OSU), s. Stefania Barwińska, s. Helena Dąbrówka (służka), s. Gloriosa Gruszka (służebniczka śląska), s. Edyta Samuk (benedyktynka). APP, Dekret Prymasa Polski z 21 kwietnia 1966 r., „Konsulta”. Skład konsulty od 1969 r.: s. Aniela Prendowska, s. Janina Wizor, s. Andrzeja Górska, s. Inez Strzałkowska, s. Gloriosa Gruszka, s. Stefania Barwińska, s. Helena Kania. APP, Dekret Prymasa Polski z 23 maja 1969 r., „Konsulta”, b.p. 
dzenia działalności, zagrożony byt oraz presja niekorzystnych uwarunkowań, nakazywały zakonom poszukiwania istotnego oparcia w Episkopacie. Nie można przy tej okazji pominąć faktu, że w ściślejszych związkach zakonów z Episkopatem, nie bez znaczenia była również sama postawa Prymasa Wyszyńskiego, a wcześniej Augusta Hlonda, protektorów życia konsekrowanego. Hierarchowie doceniali znaczenie zgromadzeń zakonnych dla Kościoła ${ }^{82}$, służyli pomocą, wskazując praktyczne rozwiązania najbardziej palących problemów ${ }^{83}$. Ważna więc była dotychczasowa, w zasadzie harmonijna oraz pożyteczna dla żeńskich zgromadzeń współpraca z kościelną hierarchią. Co więcej, zgromadzenia żeńskie, w przeważającej liczbie, miały charakter rodzimy. Posiadały domy generalne na terenie kraju. W przeciwieństwie do większości zgromadzeń męskich, nie miały umocowań i sposobności oparcia się na międzynarodowych strukturach, co mogłoby skutkować intensywniejszymi staraniami o poszerzenie autonomii ${ }^{84}$.

\section{Erygowanie i organizacja żeńskiej konferencji}

Normy z 1960 r. obowiązywały przez dziesięć lat. Po ich upływie, dn. 22 października 1970 r., Kongregacja do Spraw Zakonów i Instytutów Świeckich, erygowała Konferencję Przełożonych Wyższych Żeńskich Instytutów Zakonnych w Polsce oraz zatwierdziła jej statut. Od tego momentu konferencja działała jako kościelna osoba prawna. Statut konferencji, z niewielkimi tylko poprawkami, recypował zasadniczo sprawdzone od 1960 r. normy ${ }^{85}$.

\section{a. charakter prawny}

Konferencja Przełożonych Wyższych Żeńskich Instytutów w Polsce zdefiniowana została w statucie z 1971 r., jako zrzeszenie wszystkich wyższych przełożonych instytutów żeńskich w Polsce, działające na podstawie dyrektyw Soboru Watykańskiego II oraz Kongregacji dla Zakonów i Instytutów Świeckich (art. 1). Za członków konferencji uznano wszystkie wyższe przełożone instytutów żeńskich, jak również przełożone główne, wyznaczone przez przełożone generalne,

${ }^{82}$ Zob. AIP, S. Wyszyński, Do przełożonych wyższych zgromadzeń zakonnych żeńskich, Jasna Góra, dn. 17 września 1962 r., w: Wyszyński, Przemówienia, t. 2, s. 235-241.

${ }^{83}$ Prymas Wyszyński przestrzegał zakony przed pułapką izolacji i indywidualizmu, który tylko pozornie mógłby zabezpieczyć partykularne interesy zakonów: „Gdy okręt tonie i nasze walizy toną, trzeba ratować okręt, a nie walizy”. To motyw, który często pojawia się w wypowiedziach Prymasa Wyszyńskiego podczas spotkań z przełożonymi wyższymi. Por. AIP, Do sióstr Archidiecezji Warszawskiej, w: Wyszyński, Przemówienia, t. 2, s. 83; Łączka, Wspomnienia o wspótpracy, t. 1, s. 44;

${ }^{84}$ Wniosek o. K. Malinowskiego OFM Conv., sekretarza generalnego KWPZM, konsulatora Komisji Episkopatu ds. Instytutów Życia Konsekrowanego i Stowarzyszeń Życia Apostolskiego, b. przewodniczącego KWPZM (na podst. rozmowy z o. K. Malinowskim, styczeń 2013 r.); por. również D. Zamiatała, Zakony męskie w polityce władz komunistycznych w Polsce w latach 1945-1989. Problematyka organizacyjno-personalna, t. 1, Łomianki 2011, s. 341-351.

${ }^{85}$ APP, Statut Konferencji Przełożonych Wyżsych Żeńskich Instytutów Zakonnych w Polsce, $z$ dn. 22 października 1970 r; Dekret Prymasa Polski zatwierdzajacy Statut Konferencji Wyższych Żeńskich Instytutów Zakonnych w Polsce, $z$ dn. 8 marca 1971 r., „Konsulta”, b.p. W myśl dekretu, statut ważny był przez pięć lat. Potwierdzony został w 1976 r. Zob. Bar, Ku doskonatości zakonnej, Warszawa 1979, s. 55-58. 
mające swe siedziby poza granicami kraju (art. 2). Konferencja posiadała osobowość prawną, wynikającą z przepisów prawa kanonicznego (art. 3) ${ }^{86}$.

\section{b. związek konferencji z Episkopatem}

Nad całokształtem prac międzyzakonnych czuwał Prymas o szerokich uprawnieniach. Na mocy pełnomocnictw Stolicy Apostolskiej Prymas Polski był de facto zwierzchnikiem konferencji (art. 4), co zapewniać miało ochronę interesów zakonnych i zabezpieczyć środowiska żeńskich zgromadzeń zakonnych przed penetracją władz świeckich. Jednocześnie wpływało hamująco na rozwój niepożądanych zachowań ze strony mniej karnych instytutów, które urzędnicy państwowi nagradzać mieli przywilejami i pozytywnymi decyzjami za lojalność i działania niezależne lub niezgodne z polityką Episkopatu.

Prymas nadto mianował asystenta zakonnego (art. 4), pełniącego funkcję stałego reprezentanta Prymasa wobec konferencji. Uprawnienia asystenta pozwalały mu na mianowanie jednej spośród referentek Wydziału Spraw Zakonnych na sekretarkę konferencji. Konsulta w tej sprawie miała głos jedynie opiniujący. Wybranej przez asystenta sekretarce, przysługiwało prawo uczestniczenia $\mathrm{w}$ posiedzeniach konsulty, zebraniach plenarnych oraz spotkaniach poszczególnych sekcji. Do jej obowiązków należała organizacja konferencji, zaplanowanych przez konsultę. Prócz tego, sekretarka pełniła rolę łączniczki między konsultą a przełożonymi wchodzącymi w skład konferencji (art. 5). Statut poruszał kwestię problemów podyktowanych szczególną potrzebą chwili, w których konferencja mogła podjąć uchwałę, a po zatwierdzeniu jej przez asystenta zakonnego, wprowadzić w życie zgromadzeń (art. 5).

\section{c. cele konferencji}

Cel ogólny konferencji rozumiany był jako dążenie do rozwoju życia zakonnego i apostolstwa instytutów w Polsce. Cele szczegółowe natomiast, dotykały tematów: 1) ugruntowania i rozwoju współpracy między zgromadzeniami żeńskimi, wymiana doświadczeń, wspólna praca nad problemami formacji zakonnej, apostolstwa i budzenia powołań; 2) partycypacji zakonów żeńskich w duszpasterskiej misji Kościoła; opracowywanie wspólnych programów i przedstawianie postulatów konferencji władzom kościelnym; 3) uzgadniania wspólnego stanowiska i wystąpień w przestrzeni publiczno-prawnej, w tym, co dotyczy życia zakonnego; 4) działalności wskazanej przez Prymasa Polski bądź asystenta zakonnego $(\operatorname{art.~} 7)^{87}$.

${ }^{86}$ Dla porównania, obecnie Konferencja na mocy dekretu erekcyjnego jest kościelną kolegialną osobą prawną, upoważnioną do działania stosownie do przepisów Kodeksu Prawa Kanonicznego, kanony 115, 119, 708, 709 i innych oraz zgodnie ze swoim statutem. Konferencja ma obowiązek poszanowania autonomii poszczególnych instytutów, a jednocześnie w ramach współpracy, zobowiązana jest dążyć do jedności w działaniu i stosować się do podjętych uchwał, które jednak nie mają charakteru jurysdykcyjnego. Por. Archiwum KWPŻZZ, Statut Konferencji Wyższych Przełożonych Żeńskich Instytutów Życia Konsekrowanego i Stowarzyszeń Życia Apostolskiego w Polsce, z dn. 25 października 2007 r., rozdz. 1, art. 3 i 4.

${ }^{87}$ Obecnie, Statut KWPŻZZ jako cel ogólny Konferencji podaje pogłębianie komunii łączącej życie zakonne w Kościele, współpracę w poszukiwaniu i promocji dróg rozwoju duchowego i gorli- 


\section{d. organy konferencji}

Statut wymieniał organy konferencji (art. 8) ${ }^{88}: 1$ ) zebranie plenarne, organizowane przynajmniej raz $\mathrm{w}$ roku ${ }^{89}$; do udziału zobowiązane były konsultorki oraz przełożone wyższe, przewodniczące sekcji i członkinie sekcji klauzurowej, referentki Wydziału Spraw Zakonnych przy Sekretariacie Prymasa Polski oraz referentki diecezjalne (art. 9). Podczas zebrania plenarnego - co trzy lata - wybierano kandydatki na członkinie konsulty (siedem). Uzgadniano wspólne stanowiska wobec pojawiających się problemów i prezentowano sprawozdania konsulty oraz sekcji. Uchwalano zmiany w statucie, które jednak musiały zyskać zatwierdzenie Stolicy Apostolskiej (art. 10); 2) konsulta przełożonych wyższych; stanowić miała organ doradczy przy Prymasie Polski ${ }^{90}$, działający w imieniu przełożonych wyższych (art. 11). Statut określał liczbę konsultorek (dziewięć), z których siedem mianował Prymas na wniosek asystenta zakonnego, na okres trzech lat, spośród kandydatek wybranych przez plenum przełożonych wyższych. Do konsulty wchodziły ponadto przewodniczące sekcji klasztorów klauzurowych i sekcji zgro-

wości apostolskiej instytutów życia konsekrowanego oraz stowarzyszeń życia apostolskiego w Polsce. Wymienia ponadto sposoby realizacji powyższych celów: 1) organizowanie współpracy między zgromadzeniami w różnych dziedzinach życia zakonnego; śledzenie problemów dotyczących sytuacji zakonów, formacji, działalności apostolskiej, promocji powołań, opracowywanie wspólnych programów pracy formacyjnej i apostolskiej; 2) szukanie sposobów coraz owocniejszego włączania zgromadzeń zakonnych w działalność duszpasterską Kościoła, przy zachowaniu zawsze własnego charakteru i charyzmatu poszczególnych instytutów; wspólne planowanie, podejmowanie odpowiednich uchwał i wspólne działania, przedstawianie swych postulatów władzom kościelnym; 3) uzgadnianie wspólnych działań i zadań odnoszących się do obecności zgromadzeń zakonnych w życiu publicznym i prawnym, szczególnie w sprawach związanych z życiem konsekrowanym; 4) koordynację i współpracę z Konferencją Episkopatu Polski i z poszczególnymi biskupami; współpraca z Konferencjami Klasztorów Kontemplacyjnych, Przełożonych Wyższych Zakonów Męskich i Instytutów Świeckich w Polsce; z Międzynarodową Unią Przełożonych Generalnych (UISG) w Rzymie, z unią Konferencji Przełożonych Wyższych Europy (UCESM) oraz z innymi instytucjami związanymi z życiem konsekrowanym. Zatem poszerza się znacznie pole współpracy. Konferencja przedstawiona jest również jako autonomiczny partner, niż ściśle podporządkowana i ograniczona w swej samodzielności przez władze kościelne, jednostka. Zasadnicze cele, choć inaczej sformułowane, pozostają niezmienne, wskazując na aktualność samej idei zawiązywania konferencji wyższych przełożonych. Por. Archiwum KWPŻZZ, Statut Konferencji (2007), rozdz. 2, art. 5.

${ }^{88}$ Organami KWPŻZZ są obecnie: zebranie plenarne, przewodnicząca konferencji, konsulta, sekretarka konferencji, komisje. AKWPŻZZ, Statut Konferencji (2007), rozdz. 3, art. 8.

${ }^{89} \mathrm{~W}$ praktyce jednak dwa razy do roku (wiosna, jesień). Bar, Konferencje przełożonych zakonnych, s. 113.

${ }^{90}$ Konsulta współcześnie jest organem kierowniczym i wykonawczym konferencji wypełniającej jej cele i zadania. Odpowiada za realizację uchwał i dyrektyw ustalonych przez zebranie plenarne. Inspiruje działalność konferencji i kieruje jej pracami. Reprezentuje konferencję na zewnątrz na płaszczyźnie kościelnej i cywilnej. Członkinie konsulty są wybierane przez zebranie plenarne Konferencji. Ich kadencja trwa trzy lata. W skład konsulty wchodzą: przewodnicząca, wybierana zgodnie z przepisami prawa kanonicznego w tajnym głosowaniu, wiceprzewodnicząca i sześć konsultorek. W spotkaniach konsulty uczestniczy przewodnicząca Konferencji Przełożonych Żeńskich Klasztorów Kontemplacyjnych jako przedstawicielka swej konferencji. AKWPŻZZ, Statut Konferencji (2007) rozdz. 5, art. 9, 10 i 11. 
madzeń niehabitowych, mianowane przez Prymasa Polski. Dwie ostatnie mogły być zastąpione w wyjątkowych wypadkach przez asystentki swojej sekcji (art. 12). W wypadku ustąpienia konsultorki, Prymas na wniosek konsulty mianował jej następczynię do końca kadencji konsulty (art. 13). Konsultorki spośród siebie wybierały przewodniczą, dwie asystentki i sekretarkę konsulty (art. 14). Konsulta miała obowiązek zbierania się przynajmniej co trzy miesiące, jednak w pilnych wypadkach, mogła być zwoływana dodatkowo przez asystenta zakonnego lub przewodniczącą konsulty (art. 15). Do obowiązków konsulty należało: opracowywanie programów i organizacja zebrań plenarnych; omawianie spraw dotyczących wspólnego działania instytutów zakonnych, przygotowywanie programów kursów, dni skupienia oraz dokształcania zakonnic; czuwanie nad wykonaniem uzgodnionych programów pracy międzyzakonnej; opieka nad pracą sekcji; współpraca z Konferencją Episkopatu i konsultą zakonów męskich; w razie potrzeby przedstawianie kandydatek do Komisji Episkopatu (art. 16). Uściślone zostały zadania przewodniczącej konsulty, pełniącej jednocześnie obowiązki przewodniczącej konferencji: reprezentowanie instytutów zakonnych wobec hierarchii Kościoła; przewodniczenie obradom konsulty; przewodniczenie zebraniom plenarnym (art. 17). Obrady konsulty protokołowane miały być przez sekretarkę konsulty, która również brała na siebie odpowiedzialność za prowadzenie korespondencji (art. 17); 3) sekcje, działające w ramach konferencji, zależne w swej pracy od konsulty: zakonów klauzurowych, zgromadzeń niehabitowych, maryjna, życia zakonnego, wychowawcza, pielęgniarska, parafialna, misyjna, powołań zakonnych. Konferencja, w razie potrzeby, mogła tworzyć inne sekcje, za zgodą asystenta zakonnego (art. 18). Odpowiedzialność za sekcje spadała na konsultę, ona też ustalała jej skład, który musiał zyskać akceptację asystenta zakonnego. Ponadto wybór powinien być dokonany w porozumieniu z przełożonymi zakonnymi poszczególnych sióstr. W sekcji zakonów klauzurowych i zgromadzeń niehabitowych, członków sekcji mianował asystent zakonny, w oparciu o wybory kandydatek, dokonane przez wszystkie przełożone wyższe danej grupy instytutów zakonnych (art. 19). Sekcje działały na podstawie własnych regulaminów, zatwierdzonych przez asystenta zakonnego (art. 20).

\section{Pierwsze konsulty kanonicznej konferencji}

\section{a. działalność}

Praca zarządu wyższych przełożonych zgromadzeń zakonnych żeńskich, ujęta została w formie sprawozdań, dokumentujących działalność oraz rozwój instytucji konsulty. Poza wcześniej wymienionymi formami prac konsulty żeńskiej, na szczególną uwagę zasługują: troska o regulowanie bytu prawnego konferencji wyższych przełożonych przez korekty i przygotowywanie statutów konferencji przedkładanych władzom kościelnym do zatwierdzenia ${ }^{91}$, przygotowywanie tematyki i programu zebrań plenarnych żeńskiej konferencji wyższych przełożonych, rewizja i uzupełnianie programu szkoleń międzyzakonnych, prace nad wy-

${ }^{91}$ Przykładowo, pismo Prymasa Wyszyńskiego z dn. 12 marca 1981 r. jest odpowiedzią na pismo przewodniczącej konsulty, występującej z prośbą o przedłużenie ważności statutu konferencji, APP, Dekret z dn. 12 marca 1981 r., „Konsulta”, b.p. 
tycznymi dla formacji zakonnej, udział w pracach Komisji Episkopatu (konsultorki oraz siostry spoza konsulty wchodziły w skład następujących komisji: duszpasterstwa dobroczynnego, maryjnej ds. zakonnych, katechizacji, powołań, misji, ekumenizmu, konserwacji zabytków i sztuki, duszpasterstwa Polonii, trzeźwości oraz komisji Iustitia ed $\mathrm{Pax}^{92}$ ), rozwijanie kontaktów międzynarodowych, m.in.: udział w zjeździe rzymskim UIGS ${ }^{93}$ oraz współpraca z przełożonymi wyższymi na szczeblu międzynarodowym, udział w międzynarodowych zjazdach historyczek i archiwistek zakonnych w Paryżu; wspólne występowanie wobec władz kościelnych i państwowych $\mathrm{w}$ obronie praw i interesów żeńskich zgromadzeń zakonnych $^{94}$, kontrola realizacji programów dot. formacji, szkoleń, pracy powołaniowej, kontrola relacji: zakony żeńskie - parafie, przekazanie do Komisji Episkopatu ds. zakonnych najpilniejszych spraw: właściwego odnoszenia się duchowieństwa do sióstr podejmujących pracę parafialną, konieczność regulacji spraw materialnych (warunki mieszkaniowe i wynagrodzenie sióstr zatrudnionych w pa(rafiach $)^{95}$.

\section{b. zarządy}

Pierwsze składy konsulty po kanonicznym erygowaniu konferencji wyższych przełożonych żeńskich zgromadzeń zakonnych ${ }^{96}$ : od 1972 r.: s. Andrzeja Górska, s. Aniela Prendowska, s. Gloriosa Gruszka, s. Janina Wizor, s. Karolina Walesiak

${ }^{92} \mathrm{~W}$ pracach poszczególnych Komisji Episkopatu, udział brały wyższe przełożone i siostry reprezentujące wiele żeńskich zgromadzeń; np. w komisji: duszpasterstwa dobroczynnego - s. A. Prendowska (felicjanka), s. Krystyna Zielińska (szarytka); ds. katechizacji - s. J. Płaska (urszulanka SJK), s. B. Żukowska (zmartwychwstanka); maryjna - s. T. Sułowska (urszulanka SJK); ds. powołań - s. J. Wizor (Notre-Dame), A. Spychalska (felicjanka), s. K. Kasperkiewicz (sercanka), s. E. Okulicz (urszulanka OSU); ds. zakonnych - s. A. Spychalska, s. K. Walesiak (szarytka), s. H. Dąbrówka (służka), s. T. Sułowska (urszulanka SJK); ds. misji - s. J. Kopytiuk (franciszkanka NM), s. T. Budnowska (rodziny M.), ds. ekumenizmu - s. J. Lossow franciszkanka sł. Krzyża); ds. konserwacji zabytków i sztuki - s. Alma Skrzydlewska (służ. Krzyża); Iustitia ed Pax - s. J. Zdybicka (urszulanka SJK); ds. duszpasterstwa Polonii zagranicznej - s. M. Piątkowska (nazaretanka), s. Aniela Prendowska, s. A. Górska (urszulanka SJK), s. L. Malinowska (zmartwychwstanka); ds. trzeźwości - s. Ł. Kwietniewska (szarytka). APP, Sprawozdanie z działalności konsulty wyższych przełożonych żeńskich za okres od czerwca 1975-1978 r., „Konsulta”, b.p.

${ }^{93} \mathrm{~W}$ zjeździe rzymskim Unii w dn. 15-20 listopada 1976 r., udział wzięły: s. A. Górska (urszulanka SJK), s. Gloriosa Gruszka (służebniczka śląska), s. J. Gebel (dominikanka misjonarka). Zob. Sprawozdanie z działalności konsulty, „Konsulta”, b.p.

${ }^{94}$ Reprezentowanie interesów zgromadzeń zakonnych żeńskich przez przedstawicielki konsulty wobec władz państwowych można prześledzić analizując np. protokoły posiedzeń Zespołu ds. Zakonnych. Zob. np.: AAN, UdSW, sygn. 142/2, Protokół zebrania Zespołu do s. Zakonnych odbytego w Sekretariacie Episkopatu w dn. 22 września 1988 r., k. 1-8. Konsultę żeńską reprezentowała wówczas s. K. Dębowska, męską - ks. E. Szymanek, władze kościelne (SEP) - ks. J. Chmiel i s. M. Wojnar, natomiast stronę rządową - Z. Pijewski oraz I. Skorupska. Omawiano tematy: problemy z wypełnianiem działalności statutowej zgromadzeń zakonnych, sprawy dot. nieruchomości: nabywania n. i zakładania domów zakonnych, trudności zakonników z prowadzeniem działalności w dziedzinie oświaty, wychowania i charytatywnej.

${ }^{95} \mathrm{Na}$ przykład por. APP, Sprawozdanie z działalności konsulty, „Konsulta”, b.p.

${ }^{96}$ Do wyborów nowej konsulty w 1972 r., obowiązywał skład zarządu z poprzedniego okresu. 
(szarytka), s. Angelika Spychalska, s. Cherubina Ignaciuk (franciszkanka misjonarka Maryi) ${ }^{97}$. Od 1975 r.: s. Angelika Spychalska, s. Lucyna Ignaciuk, s. Andrzeja Górska, s. Karolina Walesiak, s. Helena Dąbrówka, s. Karolina Kasperkiewicz (sercanka), s. Aniela Prendowska, s. Gloriosa Gruszka ${ }^{98}$. Od 1978 r.: s. Angelika Spychalska, s. Andrzeja Górska, s. Irena Chorała (szarytka), s. Karolina Kasperkiewicz, s. Alma Skrzydlewska (franciszkanka SK), s. Gloriosa Gruszka, s. Milena Chorembalska (franciszkanka OC), s. Bonfilia Brzeska (córka Bożej Miłości ${ }^{99}$. Od 1981 r.: s. Angelika Spychalska, s. Alma Skrzydlewska, s. Bernarda Janusiewicz (boromeuszka), s. Bonfilia Brzeska, s. Janina Kopytiuk (franciszkanka misjonarka Maryi), s. Agnieszka Szelęgiewicz (służebniczka starowiejska), s. Kazimiera Kuc (nazaretanka), s. Stefania Kowalczyk (służka NMP) ${ }^{100}$.

W procesie kształtowania się żeńskiej współpracy międzyzakonnej w ramach konferencji wyższych przełożonych żeńskich zgromadzeń zakonnych w Polsce, ważną rolę odegrały pierwsze przewodniczące konsulty: s. Benedykta Woyczyńska $^{101}$ (1960-1962) ze zgromadzenia franciszkanek służebnic Krzyża, s. Aniela Prendowska (1963-1972) felicjanka, s. Andrzeja Górska (1972-1975) urszulanka SJK, s. Angelika Spychalska (1975-1978, następnie od 1981 r.) ${ }^{102}$.

\section{Wskazania Prymasa Wyszyńskiego dla konferencji i konsulty żeńskiej}

Podczas zebrań plenarnych wyższych przełożonych żeńskich zgromadzeń zakonnych oraz spotkań z konsultą, Prymas Wyszyński wygłaszał przemówienia programowe, których treść odnosiła się do sytuacji Kościoła powszechnego, a także Kościoła i zakonów żeńskich w Polsce ${ }^{103}$. Cezurę rozstrzygającą o wyborze tematów i priorytecie postulatów, wyznaczył Sobór Watykański II.

\section{a. przed Soborem Watykańskim II}

W przemówieniach i zaleceniach Prymasa Wyszyńskiego dominowały zasadniczo tematy związane z sytuacją polityczną w kraju i relacjami na linii państwoKościół. Obejmowały następujące zagadnienia: 1) tworzenie wspólnego frontu przeciw władzom komunistycznym atakującym Kościół w Polsce, w tym życie zakonne; 2) posłuszeństwo zakonnic władzom kościelnym; 3) kontakty sióstr z przedstawicielami władz świeckich; 3) włączanie się sióstr zakonnych w pracę parafialną; 4) katechizacja szkolna i pozaszkolna; 5) podnoszenie kwalifikacji zawodowych i poziomu wiedzy religijnej w zgromadzeniach żeńskich; 6) godne i należyte wypełnianie urzędu przełożeńskiego ${ }^{104}$.

${ }^{97}$ APP, Dekret Prymasa Polski z 18 maja 1972 r., „Konsulta”, b.p.

${ }^{98}$ APP, Dekret Prymasa Polski z 31 kwietnia 1975 r, „Konsulta”, b.p.

${ }^{99}$ APP, Dekret Prymasa Polski z 25 kwietnia 1978 r., ,Konsulta”, b.p.

${ }^{100}$ APP, Dekret Prymasa Polski z 1981 r, „Konsulta”, b.p.

${ }^{101}$ S. Benedykta, Wiesława Kruszewska Woyczyńska (1901-1975), franciszkanka służebnica Krzyża; dr filozofii, nauczycielka, bliska współpracowniczka s. Róży Czackiej; 1950-1962 przełożona generalna zgromadzenia. Wyszyński, Pro memoria, s. 709.

${ }^{102}$ Bar, Konferencje wyższych przetożonych, s. 111.

${ }^{103}$ Informacja od s. K. Dębowskiej (na podst. rozmowy z Autorką, styczeń 2013 r.).

${ }^{104}$ Obszerna dokumentacja wystąpień Prymasa i przemówień do przełożonych wyższych znajduje się w AIP w maszynopisach ułożonych chronologicznie w teczkach pt.: Przemówienia do sióstr zakonnych. 
W pierwszym okresie współpracy z wyższymi przełożonymi zgromadzeń żeńskich, szczególnie istotne było budowanie wspólnej linii obrony przed zagrożeniami wynikającymi z polityki wyznaniowej państwa. Prymas Wyszyński uwrażliwiał przełożone, by postępowały roztropnie z władzami świeckimi, przestrzegał przed naiwnością, ostro krytykował nieuczciwą dyplomację, płaszczenie się niektórych przełożonych, załatwiających sprawy zgromadzenia z pracownikami państwowymi, bez pośrednictwa Wydziału Spraw Zakonnych ${ }^{105}$. Ubolewał, że o takiej lojalistycznej postawie wobec komunistów, decydowały najczęściej sprawy materialne. Upominał: zagrożenie jest wspólne, stąd obrona musi być wspólna. Nie zawsze pomoże działanie na własną rękę, musi być jakaś solidarność w obronie życia i bytu zgromadzeńn ${ }^{106}$.

Ksiądz Prymas wymagał od przełożonych wyższych współpracy z wizytatorami kościelnymi, na których nałożył obowiązek porządkowania działalności i życia zgromadzeń zakonnych. Zwracał publicznie uwagę na wypadki niemożności przeprowadzenia wizytacji kanonicznej, z powodu odmowy niektórych przełożonych wyższych ${ }^{107}$. Prosił o poważne potraktowanie sprawy, przez podjęcie współpracy z Wydziałem Spraw Zakonnych oraz wyznaczanie odpowiednich sióstr do pracy w charakterze referentek WSZ. Jednocześnie ks. Prymas dbał, by siostry referentki, związane z WSZ nie były we własnych zgromadzeniach traktowane niesprawiedliwie, czy nawet dyskryminowane lub lekkomyślnie oskarżane o brak ducha zakonnego. Prymas Wyszyński podkreślał odpowiedzialność przełożonych za zgromadzenia i sprawowany urząd ${ }^{108}$.

W związku z rugowaniem sióstr zakonnych ze szkół oraz usuwaniem lekcji religii, w przemówieniach do przełożonych wyższych i konsulty, na przełomie lat 50. i 60 . XX w., podejmowany był z kolei temat katechizacji ${ }^{109}$.

\section{b. odnowa soborowa}

Prymas Wyszyński jeszcze przed Vaticanum II, uwrażliwiał wyższe przełożone na przełom, jaki przyniesie zbliżający się sobór powszechny ${ }^{110}$. Po soborze, zrażony rozumieniem odnowy zakonnej przez niektóre, rzekomo postępowe zgromadzenia zakonne, na zachodzie Europy, przestrzegał konsultę i przełożone wyższe przed powierzchownymi reformami, które doprowadziłyby do deformacji

${ }^{105}$ AIP, S. Wyszyński, Do przełożonych wyższych zgromadzeń zakonnych żeńskich, 25 maja 1959 r., Warszawa, w: Przemówienia, t. 1, s. 155-173.

${ }^{106}$ AIP, Tenże, Do przełożonych wyższych zgromadzeń zakonnych żeńskich, 7 listopada 1960 r., Jasna Góra, Warszawa, w: Przemówienia, t. 1, s. 282-301.

${ }^{107}$ AIP, S. Wyszyński, Przełożone zakonne wspótpracuja z Kościołem. Do przełożonych wyższych zgromadzeń zakonnych żeńskich, Jasna Góra, dn. 8 października 1957 r., w: Przemówienia, t. 1 , s. 59-74.

${ }^{108}$ Por. tamże; APP, Pielgrzymka Przełożonych Wyższych Zgromadzeń Zakonnych Żeńskich na Jasnej Górze, w dn. 8-10 października 1957 r., „Konsulta”, b.p.

${ }^{109}$ AIP, S. Wyszyński, Do matek konsultorek i referentek diecezjalnych, 22 sierpnia 1958 r., Warszawa, w: tenże, Przemówienia, s. 125-130; AIP, S. Wyszyński, Do przełożonych zgromadzeń zakonnych żeńskich, 24 grudnia 1958 r., Warszawa, w: Przemówienia, t. 1, s. 145-150.

${ }^{110}$ AIP, S. Wyszyński, Do przełożonych wyższych zgromadzeń zakonnych żeńskich, Warszawa, dn. 5 maja 1961 r., w: Przemówienia, t. 3, s. 25-26. 
i zniszczenia życia zakonnego. Zalecał rozwagę, unikanie pseudoteologii, publicystyki, oraz pogłębianie znajomości tekstów źródłowych. Nakazywał obowiązkową lekturę dokumentów Soboru Watykańskiego II, nie tylko wyższym przełożonym, ale również przez przełożonych, każdej siostrze ${ }^{111}$. Zwracał uwagę konsultorek na soborowe postulaty przystosowanej do współczesności odnowy życia zakonnego i związanie zakonów z życiem Kościołów lokalnych - parafią, diecezją, ale też doceniał, np. przy okazji dwudziestolecia współpracy z przełożonymi wyższymi, dotychczasowe zaangażowanie zakonów żeńskich w pracę Kościoła w Polsce ${ }^{112}$. Z uznaniem wypowiadał się o działalności konsulty, za pośrednictwem której, z nauką soborową, mógł dotrzeć do każdego żeńskiego zgromadzenia zakonnego w Polsce ${ }^{113}$.

\section{Praca sekcji/komisji}

Konferencja wyższych przełożonych działała w oparciu o sekcje, które zawiązały się początkowo przy Wydziale Spraw Zakonnych dla lepszego zorganizowania pracy międzyzakonnej ${ }^{114}$. Z chwilą erygowania żeńskiej konferencji wyższych przełożonych, sekcje stały się organem konferencji, podporządkowanym konsul-

${ }^{111}$ AIP, S. Wyszyński, Do konsulty męskiej i żeńskiej, Warszawa, dn. 22 stycznia 1969 r., w: Przemówienia, t. 4, s. 84-97; Do sióstr archidiecezji warszawskiej, Warszawa 4 sierpnia 1969 r., s. 134; Prawdziwa odnowa soborowa życia zakonnego. Do przełożonych wyższych zgromadzeń zakonnych żeńskich, Jasna Góra, dn. 5 września 1969 r., s. 147-159.

${ }^{112}$ AIP, S. Wyszyński, Do przełożonych wyższych zgromadzeń zakonnych żeńskich, Jasna Góra, dn. 6 maja 1969 r., w: Przemówienia, t. 4, s. 109-125.

${ }^{113}$ AIP, S. Wyszyński, Do sióstr archidiecezji warszawskiej, Warszawa 4 sierpnia 1969 r., w: Przemówienia, t. 4, s. 134.

114 1) Sekcja szkolno-wychowawcza, początkowo tzw. komisja szkolna, powstała w $1950 \mathrm{r}$. Prowadzona była przez dyrektorki szkół zakonnych. Likwidowanie szkół przyczyniło się do przekształcenia sekcji w wychowawczą, z poszerzonym gronem pracowników - o dyrektorki domów dziecka, zakładów specjalnych, przedszkoli i internatów. Celem sekcji było prowadzenie szkoleń, a także zabezpieczenie interesów zakonnych placówek oświatowo-wychowawczych przed ingerencją państwa. Od strony kościelnej sekcją kierował ks. A. Słomkowski, były rektor KUL. Por. S. Wyszyński, Przemówienie do sióstr wychowawczyń, Wawer 1961 r., w: Przemówienia, t. 2, s. 72-75.

2) Sekcja parafialna powstała w $1951 \mathrm{r}$. Jej celem była pomoc siostrom zakonnym, które po starcie miejsc pracy, masowo przechodziły do pracy parafialnej. Nad sekcją czuwał ks. bp B. Kominek. Szczególnie pilne problemy, którymi zajmowała się sekcja, to szkolenia i formacja tzw. sióstr parafialnych, a także uregulowanie relacji między księżmi a siostrami, zwłaszcza przez umowy o pracę, a także troskę o należyte traktowanie sióstr i ich zadań podejmowanych w parafii. Przechodzenie sióstr do pracy parafialnej, kontrolowane było przez pracowników UdSW. Por. AAN, UdSW, sygn. 133/14, Notatka informacyjna dot. dziatalności zakonów w Polsce, k. 3.

3) Sekcja maryjna wyodrębniła się w 1959 r. i włączyła zgromadzenia zakonne w prace Wielkiej Nowenny. Wydawała biuletyn maryjny. W 1981 r. przekształciła się w komisję maryjną przy konsulcie wyższych przełożonych żeńskich zgromadzeń.

4) Sekcja pielęgniarska powstała w 1950 r. z dawnej komisji pielęgniarskiej. Jej szczególnym dorobkiem było stworzenie szkoły pielęgniarskiej dla sióstr. Prace sekcji we wczesnym okresie przedstawia s. Adela Łączka w swoich Wspomnieniach o wspótpracy miedzyzakonnej. 
cie. Sekcje: zakonów klauzurowych ${ }^{115}$, zgromadzeń niehabitowych ${ }^{116}$, maryjna, życia zakonnego, wychowawcza, pielęgniarska, parafialna, misyjna, powołań zakonnych - z czasem zostały przemianowane i funkcjonowały jako komisje ${ }^{117}$. Organizacja pracy poszczególnych sekcji/komisji, skład personalny, odpowiedzialność konsulty za prace sekcji oraz sprawy powiązań sekcji z Wydziałem Spraw Zakonnych, omawiane były podczas zebrań konsulty ${ }^{118}$. Wytycznych pracowniczkom sekcji udzielał niejednokrotnie sam Prymas Wyszyński. Zauważając na przykład usuwanie zakonnic z placówek oświatowych i wychowawczych, zachęcał siostry z sekcji szkolno-wychowawczej do animowania nowych form pracy wychowawczej wśród dzieci i młodzieży w oparciu o struktury parafialne ${ }^{119}$. Ukierunkowywał i inspirował pracę sekcji, wskazując nowe możliwości zaangażowania sióstr: konieczność wsparcia rodzin, zwłaszcza wielodzietnych i borykających się z problemami wychowawczymi ${ }^{120}$. Dokładny obraz prac sekcji/komisji przedstawiały przewodniczące sekcji w szczegółowych sprawozdaniach. Sprawozdania były składowym i uzupełniającym elementem sprawozdawczości prezentującej pracę konsulty ${ }^{121}$.

\section{Działalność żeńskiej konferencji i konsulty w opiniach władz PRL}

Zgromadzenia żeńskie postrzegane były przez władze komunistyczne jako bardziej konserwatywne i uległe wobec kierownictwa Episkopatu, aniżeli męskie $^{122}$. Takie oceny dotyczyły działalności konferencji wyższych przełożonych żeńskich zgromadzeń zakonnych oraz konsulty, przez które, jak zauważano, budowana była wspólna linia postępowania zgromadzeń żeńskich wobec władz państwowych. Ks. Prymas miał powoływać ośrodki koordynujące działalność żeń-

${ }^{115} \mathrm{~W}$ pracy sekcji zakonów klauzurowych, szczególnie aktywną była s. Klaudia Niklewicz, prezes Federacji Klasztorów Sióstr Wizytek w Polsce, wieloletnia przewodnicząca sekcji klauzurowej (na mocy statutu, przewodnicząca sióstr klauzurowych wchodziła w skład konsulty). Zob. APP, Dekret z dn. 14 sierpnia 1968 r.; Dekret z dn. 24 września 1979 r., „Konsulta”, b.p.

${ }^{116}$ Wśród zgromadzeń niehabitowych, wyróżniała się m.in. s. Helena Dąbrówka, mianowana przez Prymasa Wyszyńskiego przewodniczącą sekcji w 1969. Zob. APP, Dekret z dn. 31 maja 1969 r., „Konsulta”, b.p.

${ }^{117}$ Informacja od s. Krystyny Dębowskiej (na podst. rozmowy z Autorką, styczeń 2013 r.). Przekształcenie sekcji w komisje potwierdza analiza statutów Konferencji Wyższych Przełożonych Żeńskich Zgromadzeń Zakonnych. W statucie zatwierdzonym 13 stycznia 1976 r. mowa jest o sekcjach, które są organami konferencji, zależnymi od konsulty, natomiast w statucie z dn. 27 października 1981 r. w miejscu sekcji pojawiają się komisje międzyzakonne.

118 Zob. np. APP, Sprawozdanie z działalności konsulty wyższych przełożonych żeńskich za okres od czerwca 1975 do 1978 r., s. 3, „Konsulta”, b.p.

${ }_{119}$ AIP, S. Wyszyński, Do sióstr zakonnych, Warszawa, 1972 r., w: Przemówienia do zakonnic, inw. 9245 , b.p.

${ }^{120}$ Por. AIP, Do sióstr wychowawczyń, Wawer, 1961 r., w: Przemówienia, t. 2, s. 72-75

${ }^{121}$ Zob. APP, Sprawozdanie z działalności konsulty wyższych przełożonych żeńskich za okres od czerwca 1975 do 1978 r., s. 3, „Konsulta”, b.p. Do sprawozdań konsulty dołączane były obszerne sprawozdania z prac poszczególnych sekcji, które autorowi artykułu nie zostały udostępnione.

${ }^{122}$ AAN, UdSW, sygn. 133/12, Zadania do pracy z zakonami. Tezy do rozmów z prowincjałami, k. 3 . 
skich zakonów jako organy wytyczające ogólne kierunki dla wszystkich instytutów żeńskich, zbieżne z polityką Kościoła w Polsce ${ }^{123}$. Uważano wiec, że Prymas Wyszyński doprowadzając do silnej centralizacji władzy nad zakonami żeńskimi, uzyskał możliwość jednolitego programowania pracy wszystkich instytutów w Polsce ${ }^{124}$.

W związku zaistniałą sytuacją, za najbardziej adekwatne, uznano działania dążące do uniezależnienia zakonów żeńskich od Prymasa i struktur kościelnych. Przestrzegano, że dotychczasowe posunięcia, takie jak: pozbawianie zakonnic możliwości wykonywania pracy zawodowej w instytucjach społecznych, a także ograniczenia majątkowe, w konsekwencji spowodowały szeroki napływ zakonnic do działalności pomocniczej $\mathrm{w}$ parafiach, a przez to, powiązanie żeńskich zakonów z hierarchią kościelną w kraju. Niepokojono się intensywną współpracą zakonów żeńskich z poszczególnymi kuriami i biskupami ${ }^{125}$. Zdecydowano się więc, na rozbijanie jedności zgromadzeń żeńskich z Episkopatem, m.in. przez wzmacnianie tych instytutów, które opowiadały się za ułożeniem wzajemnych relacji, według wytycznych Urzędu do Spraw Wyznań. Wypunktowane nawet zostały tzw. kryteria lojalności, według których uznawano zgromadzenia za mniej lub bardziej propaństwowe. Zwracano jednocześnie uwagę, by regulowanie spraw $\mathrm{z}$ instytutami odbywało się $\mathrm{w}$ indywidualnych, bezpośrednich kontaktach z przełożonymi zgromadzeń, unikając ośrodków centralnych, a zwłaszcza pośrednictwa Wydziału Spraw Zakonnych. Postanowiono nawet wykorzystać dokumenty Kościoła $\mathrm{w}$ antagonizowaniu konferencji wyższych przełożonych z Prymasem Wyszyńskim, posługując się sugestywną argumentacją: w Polsce - jak wiadomo Episkopat zmierza do ograniczenia władz konferencji wyższych przełożonych do spraw wewnątrzzakonnych, do całkowitego odsunięcia jej od wpływu na strategię Kościoła, a nawet do niedoinformowania tej instytucji w zakresie stosunków między Państwem a Kościołem ${ }^{126}$.

Wymienione fakty wskazują, jak bardzo mogło władzom komunistycznym nie odpowiadać absolutne posłuszeństwo ${ }^{127}$ żeńskiej konferencji i konsulty, Prymasowi Wyszyńskiemu ${ }^{128}$. Pracownicy Urzędu do Spraw Wyznań, zdawali sobie

${ }^{123}$ AAN, UdSW, sygn. 142/1, Informacje o aktualnej sytuacji i zadaniach w pracy z zakonami, k. 138. W tej samej notatce czytamy, że kontrolę nad stosowaniem się zakonów do wytyczonej linii działania, sprawował Sekretariat Episkopatu, a zwłaszcza Wydział Spraw Zakonnych.

${ }^{124}$ AAN, UdSW, sygn. 133/12, Informacja o aktualnej sytuacji i zadaniach w pracy z zakonami, k. 88 .

${ }^{125}$ AAN, UdSW, sygn. 133/12, Notatka w sprawie ożywienia kontaktów z duchowieństwem, $\mathrm{k}$. 65-67.

126 Tamże.

127 „Jeśli nie obronimy zasadniczej sprawy Kościoła, nie obronimy zakonów (...). Domagam się posłuszeństwa absolutnego i mogę liczyć na to absolutne posłuszeństwo. Mam uprawnienia, gdybym dostrzegł, że są zarządzenia przełożonych inne, będę zmieniał, tego wymaga dobro Kościoła. Stoję na stanowisku prawa zakonnego, ale gdy jest dobro wyższego rzędu, musi wziąć ono górę. AWSZ II - 2/5, Przemówienie Prymasa Wyszyńskiego do MM. Konsultorek i SS. Referentek Diecezjalnych z dn. 22 sierpnia 1958 r., s. 3.

${ }^{128}$ K. Dębowska, Referat wygłoszony podczas konferencji Plenarnej KWPŻZZ w Warszawie, dn. 24 kwietnia 2001 r.: «Co zgromadzenia żeńskie zawdzięczaja Prymasowi?», Warszawa 2001, (mps w posiadaniu autora). 
jednocześnie sprawę, jak Prymas, chronił konsultę i wyższych przełożonych przed prowokacyjnym postępowaniem przedstawicieli władz państwowych ${ }^{129}$.

\section{Dorobek żeńskiej konferencji i konsulty w PRL}

Istotne osiągnięcia konferencji i konsulty okresu PRL to roztropne wdrażanie reform soborowych w zgromadzeniach żeńskich ${ }^{130}$, odnowa liturgiczna, pogłębianie procesu demokratyzacji (zmiana ordynacji wyborczych, większy udział ogółu sióstr $\mathrm{w}$ tworzeniu nowego prawa partykularnego zgromadzeń poprzez ankiety, konsultacje, prace w komisjach), uregulowanie stanu prawnego zgromadzeń, dostosowanie konstytucji zgromadzeń żeńskich do zaleceń Kościoła ${ }^{131}$, większa troska o przygotowanie sióstr do pełnionych zadań (wyrównanie wykształcenia sióstr na poziomie średnim, wzrost liczby sióstr z wykształceniem wyższym), przedłużenie okresu formacji sióstr, wprowadzanie formacji permanentnej, udział zgromadzeń w wielkich akcjach w Ojczyźnie (Nowenna przed Millenium, obchody Tysiąclecia Chrztu Polski w 1966 r., czuwania i czyny soborowe, stała modlitwa za Ojczyznę, zwłaszcza podczas kolejnych zrywów wolnościowych w narodzie: $1956,1970,1980^{132}$.

W latach 80 . XX w. dla konsulty i konferencji żeńskich zgromadzeń zakonnych w Polsce, szczególnie istotne były następujące wydarzenia: 1) śmierć Prymasa Wyszyńskiego, zamykająca dotychczasowe, tak bezpośrednie zaangażowanie Prymasa Polski w sprawy konferencji wyższych przełożonych; 2) napięta sytuacja polityczna w Ojczyźnie; 3) przemiany w państwie i Kościele po roku $1989^{133}$.

Istotne zmiany w statusie Konferencji Wyższych Przełożonych Żeńskich Zgromadzeń i konsulty żeńskiej w Polsce, przyniósł dopiero rok 1989. Nowe warunki polityczne pozwoliły na otworzenie Nuncjatury Apostolskiej. Po pół wieku nieobecności, przywrócono stosunki dyplomatyczne między Polską a Stolicą Apostolską. Nie było już potrzeby udzielania specjalnych pełnomocnictw Prymasowi Polski. Konferencja Wyższych Przełożonych Żeńskich Zgromadzeń Zakon-

${ }^{129}$ Obrona prowadzona była m.in. w formie szkoleń. AAN, UdSW, sygn. 142/79, F. Bogdan, Referat wygłoszony dla Wyższych Przełożonych Zakonnych, dn. 26 września 1978 r. w Częstochowie: $O$ nowym dokumencie Stolicy Apostolskiej $w$ sprawie relacji miedzy biskupami a rodzinami zakonnymi, k. 86.

${ }^{130}$ Konsultorki i wyższe przełożone uczestniczyły w specjalnych szkoleniach. Przykładowo zob. AIP, Dni skupienia wyższych przełożonych zgromadzeń zakonnych żeńskich, Jasna Góra, dn. 11-14 września 1968 r: abp B. Kominek: Podstawy współczesnej teologii apostolstwa; bp I. Tokarczuk, Przemiany wspótczesnego świata i wynikające stąd zadania apostolskie; bp B. Dąbrowski, Działalność apostolska i dobroczynna istotnym elementem czynnego życia zakonnego; ks. A. Żuchowski, Przystosowanie życia wspólnego w związku z nowymi formami działalności apostolskiej $i$ dobroczynnej.

${ }^{131}$ Na przykład: D. Gniadek, Recepcja wskazań soborowych dotyczacych odnowy ewangelizacji w Zgromadzeniu Sióstr Stużebniczek BDNP, Warszawa 1994, s. 29-52 (mps w bibliotece domu prowincjalnego służebniczek śląskich w Warszawie).

${ }^{132}$ Dębowska, Referat wygloszony podczas konferencji Plenarnej KWPŻZZ w Warszawie, $d n$. 24 kwietnia 2001 r.: «Co zgromadzenia żeńskie zawdzięczają Prymasowi?» (b.p.)

${ }^{133} \mathrm{Na}$ podst. rozmowy z s. K. Dębowską, styczeń $2013 \mathrm{r}$. 
nych uzyskała więc faktyczną autonomię ${ }^{134}$. Polska współpraca międzyzakonna zdynamizowała swoją działalność, wyspecjalizowała się oraz odważniej otworzyła na Europę i świat ${ }^{135}$.

słowa kluczowe: zakony żeńskie, przełożone żeńskich zakonów, konferencja, Polska Rzeczpospolita Ludowa, polityka wyznaniowa

\title{
THE CONFERENCE OF MAJOR SUPERIORS OF FEMALE RELIGIOUS OR- DERS AND THE CONSULTA IN THE POLISH PEOPLE'S REPUBLIC-AN OUTLINE
}

\begin{abstract}
Summary
The formation process of the institutions of the Conference of Major Superiors of Female Religious Orders in Poland started in the period in which there had already been some structures of the cooperation between convents, developed for the common defence of nuns against the negative effects of the religious policy of the communist authorities, the policy which was aimed at the liquidation of the institution subordinate to the Church, including religious orders. The interaction of female religious congregations was the answer to the necessity of the consolidation of forces and construction - under the guidance of Polish Primate S. Wyszyński - common programmes, the aim of which was to help the

${ }^{134}$ Dębowska K., Życie konsekrowane, jego istota i aktualna sytuacja w Polsce, w: Leksykon zakonów w Polsce, s. 17-18. Obecnie członkinie konferencji uczestniczą w pracach Komisji Mieszanej biskupi - przełożeni wyżsi i Komisji Konferencji Episkopatu Polski ds. Życia Konsekrowanego, a także jako konsultorki w innych Komisjach Episkopatu. KWPŻZZ jest członkiem Europejskiej Unii Konferencji Przełożonych Wyższych (UCESM) z siedzibą w Brukseli, a część przełożonych generalnych należąca do Konferencji jest członkami Międzynarodowej Unii Przełożonych Generalnych w Rzymie i ma swoją delegatkę w radzie poszerzonej Unii (Informacja uzyskana z Sekretariatu KWPŻZZ).

${ }^{135}$ Dzisiaj w Polsce istnieje Konferencja Wyższych Przełożonych Żeńskich Zgromadzeń Zakonnych (KWPŻZZ), Konferencja Wyższych Przełożonych Zakonów Męskich (KWPZM), Konferencja Przełożonych Żeńskich Klasztorów Kontemplacyjnych (KPŻKK) oraz Krajowa Konferencja Instytutów Świeckich (KKIŚ). Konferencja Episkopatu utworzyła specjalną Komisję Instytutów Życia Konsekrowanego i Stowarzyszeń Życia Apostolskiego; istnieje również Komisja Mieszana: biskupi - wyżsi przełożeni zakonni (zob. Regulamin działania Komisji Mieszanej: Biskupi i Wyżsi Przełożeni Zakonni - w świetle dokumentu Mutuae Relationes, dostępny w Sekretariacie KWPMZZ). W każdej diecezji - najczęściej w randze wikariusza biskupiego - pracuje osoba odpowiedzialna za życie konsekrowane. Por. Życie konsekrowane w Polsce na początku nowego tysiaclecia, s. 72-73.
\end{abstract}


religious congregations survive and function in the communist reality.

The evolution of the cooperation forms: from the spontaneous and regulated by law the Conference of Major Superiors of Female Religious Orders, with the statute approved by the Holy See and canonically erected consulta, overlapped with similar movements of the consecrated life in the world. In the realities of the Polish People's Republic, the Conference was not as autonomous as was formulated by canon law under normal conditions. The Conference had to be in a close relationship with Primate S. Wyszyński and the Department of Monastic Affairs, created by the Primate, who in practice gained control over the entire existing cooperation between religious orders. Regardless of the factual and legal restrictions on the activities of the Conference and its consulta, which was essentially an advisory body to the Polish Primate, the achievements of that institution for the religious life in Poland were extremely significant, which was reflected primarily in: the prudent implementation of the conciliar reforms in religious congregations, their liturgical renewal, deepening the democratization process, regulating the legal status, changes in the substantial and permanent formation of the members of congregations.

Keywords: female religious orders, Superiors of female religious orders, conference, Polish People's Republic, religious policy 